\title{
An Analysis of the Payment Habits of Hungarian Micro, Small and Medium-sized Enterprises - In Focus: Cash Usage*
}

\author{
Ágnes Illés Belházy - Tamás Végső - Anikó Bódi-Schubert
}

In this study, we examine the cash usage of Hungarian micro, small and mediumsized enterprises along with the main reasons behind the use of cash by analysing data from a questionnaire-based survey conducted on a sample comprising 1,000 corporate managers. In this context, we study the payment habits of enterprises, their ties with financial institutions, the degree of distrust in the Hungarian corporate sector and potential tools for the reduction of cash usage. Wherever possible, we compare our results to the conclusions of previously published Hungarian or foreign research conducted with a similar focus. According to our most important findings, credit transfer is clearly the most prominent payment method both in the SME sector and among microenterprises, but the rate of cash usage is also high and it does not exhibit a declining trend. Positive changes can be observed, however, in payment discipline and business confidence. Hungarian enterprises are loyal to their account manager banks, and although they are essentially open to electronic payment solutions they are highly sensitive to the associated costs.

Journal of Economic Literature (JEL) codes: G30, G32, L14

Keywords: SME sector, microenterprises, cash usage, payment habits, business confidence, credit institution preferences, electronic payment solutions

\section{Introduction}

Based on the data of the HCSO (2017), in 2016 a total of 687,698 micro, small and medium-sized enterprises were operating in Hungary. In terms of quantity, this sector accounts for 99.1 per cent of Hungarian businesses and provides employment to more than two thirds of the employees in the corporate sector. In addition, it contributes to the total performance of Hungarian enterprises with 43 per cent of value added and 42 per cent of net sales. It is clear, therefore, that the enterprises

\footnotetext{
* The papers in this issue contain the views of the authors which are not necessarily the same as the official views of the Magyar Nemzeti Bank.

Ágnes Illés Belházy is Senior Cash Policy Expert at the Magyar Nemzeti Bank. E-mail: belhazynea@mnb.hu Tamás Végső is Junior Cash Policy Expert at the Magyar Nemzeti Bank. E-mail: vegsot@mnb.hu Anikó Bódi-Schubert is Head of Department at the Magyar Nemzeti Bank. E-mail: schuberta@mnb.hu
}

The Hungarian manuscript was received on 26 February 2018.

DOI: http://doi.org/10.25201/FER.17.4.5394 
in the SME sector play a prominent role in the Hungarian economy and thus, in payment transactions. Their payment practices and attitude towards cash usage may influence the habits of society as a whole, especially since the overwhelming majority of these businesses operates in the services sector. Excessive cash usage by enterprises undermines the transparency of the sector and impedes control over their activity. Consequently, exploring the underlying reasons of the phenomenon, obtaining an in-depth understanding of corporations' payment habits and analysing their motives for a more widespread use of electronic payment solutions may be of particular importance from an economic perspective.

The main purpose of our study is to measure the role of cash payments in the business transactions of Hungarian micro, small and medium-sized enterprises and examine their primary motives for the use of cash. We also attempt to gain a deeper understanding of the business environment in which payments are generated in the business-to-business (B2B) transactions of enterprises, including payment methods and terms, payment discipline and financial management awareness. We consider the latter aspect particularly important in the sector under review because overdue account receivables or potential bad debts may give rise to serious liquidity problems in corporate operations which, in severe cases, may even limit the enterprise's growth potential or jeopardise its operability. Partly in connection with the previous point, we also assess the financial institution habits of the enterprises concerned as well as their requirements and preferences regarding their account manager credit institution.

In our research, we partly repeated a survey conducted in 2013 with a similar focus, which was aimed at assessing the role of cash in the execution of transactions among the enterprises of the Hungarian SME sector. The results of the survey were summarised in the study by Bódi-Schubert (2014). As that survey was conducted during the recovery period directly following the economic crisis, the author specifically addressed the issue of trust between enterprises and sought to explore whether the degree of trust could influence the choice between payment methods in practice. Given that the economic environment has significantly improved over the past five years, for the purposes of the 2017 survey we did not place special emphasis on this particular dimension.

The previous, 2013 survey focused on the cash payment habits of small and medium-sized enterprises only. However, since the number of these enterprises is only a fraction of that of microenterprises (according to the data presented in HCSO 2017, in 2016 649,733 microenterprises operated in Hungary while small and medium-sized enterprises comprised only 37,965 firms) and since microenterprises have a particular propensity to use cash owing to their cost sensitivity and low-value transactions, we also involved this sector in our current study. In our survey we did not focus on the sector of large corporations in view of the fact that, based on data 
from annual reports, they are less likely to pay in cash; in addition, the client and supplier assessment practices and liquidity management of large corporations can be almost always considered professional.

\section{Research methodology}

Similar to the 2013 survey, in the survey conducted in 2017 we relied on quantitative and qualitative tools to examine the correlations between payment habits and cash usage in the customer and supplier positions among Hungarian small and mediumsized enterprises (including, in particular, microenterprises). Commissioned by the Magyar Nemzeti Bank (MNB), the survey was conducted by the Századvég School of Politics Foundation.

In the qualitative phase, personal interviews were conducted with 10 enterprises (6 SMEs and 4 microenterprises). In the quantitative phase, the effective sample size was 500 for microenterprises and for the SME sector alike, with each sample comprising Hungarian firms of heterogeneous activities. The survey was taken solely via phone interviews; the questions asked are presented in the Annex. Figure 1 presents the composition of the quantitative samples - which contain the enterprises participating in the 2017 and 2013 surveys - by activity; the deviation from the actual proportions of Hungarian enterprises based on HCSO data was corrected in the databases by way of weighting. Within the individual activity sectors, the sample is not considered to be representative; moreover, the number of respondents belonging to the same groups on this basis is fairly low; consequently, the suitability of the quantitative results to analyse correlations between the core activity and the payment and cash usage habits of the enterprises is limited.

In the case of microenterprises, the respondents representing the interviewed enterprises were owners/managing directors in every case, whereas the respondents of small and medium-sized companies were owners in 26.8 per cent, managing directors/managers in 46.7 per cent and CFOs/finance managers in 26.6 per cent of the cases. For both enterprise types the questionnaires began with screening questions and questions about the general characteristics of the enterprise concerned (number of employees, net annual sales), followed by questions designed to explore supplier and customer relationships, payment habits regarding the payment of wages and utility bills and the motivations behind the use of cash. The final set of questions of the questionnaires addressed the impact of the administrative measures on payment transactions, the incentives encouraging the reduction of cash usage and aspects of the enterprises' credit institution relations (bank selection, bank switching). 


\section{Figure 1 \\ Composition of the samples containing the enterprises participating in the survey by core activity vs. real composition based on HCSO data (\%)}

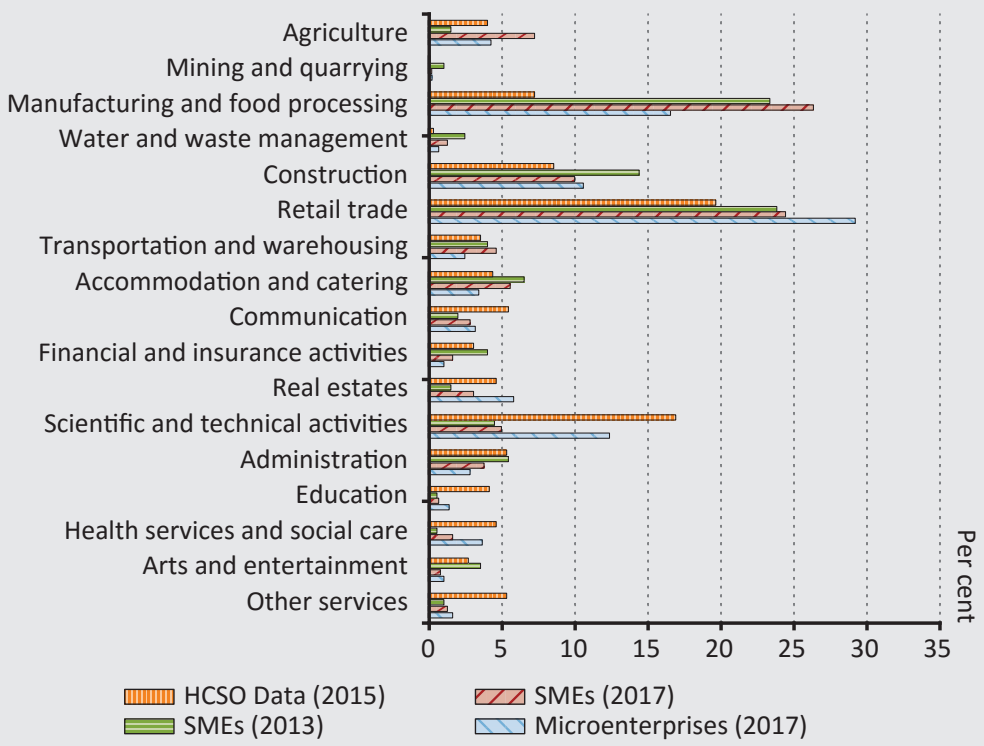

Note: Source of HCSO data: Number of active corporations by industries. https://www.ksh.hu/docs/hun/ xstadat/xstadat_eves/i_qpg008.html. Downloaded: 12 January 2018

The qualitative survey involved ten semi-structured, theme-oriented interviews conducted in April 2017. The respondents were decision-makers at Hungarian small and medium-sized enterprises in all cases. The selection method ensured that the respondents were able to share their experiences in managing Hungarian enterprises with different activities and geographical locations. The structure of the interviews partly followed the structure of quantitative questionnaires. The clarification of the enterprise's activity and the subject's role in it was followed by a general overview of the supplier and customer relationships. Next, the interview focused on the details of payment transactions and cash usage and on topics related to the relevant experiences of the respondents. The qualitative round of the survey was performed with a view to testing and fine-tuning the questionnaire and in order to gain an initial view on the features of payment practices among the enterprises concerned. Summarising the results and conclusions of the interviews we found that the responses of the interviewees confirmed the results of the quantitative survey in almost every topic. Therefore, in presenting the results of the survey our analysis is restricted to the data of the questionnaire-based survey. 


\section{Survey results}

In this chapter, we present the results of the 2017 quantitative survey in detail and compare them, wherever methodologically possible, to the results of the 2013 survey. Further comparative analysis is hampered by the fact that articles on cash usage and payment habits are typically limited to the examination of households (for example, Ilyés - Varga 2015, Esselink - Hernández 2017), while the literature on the SME sector addresses, for the most part, credit conditions and the growth potential of enterprises (for example, Banai et al. 2016, Bethlendi - Végh 2014). In an international context, the only similar survey available to us was the one commissioned by the British tax authority ${ }^{1}$ and conducted by Ipsos MORI Social Research Institute ( $T u$-Salmon 2016), the relevant results of which are presented in Sub-chapter 3.1. Our study focuses on enterprises with less than 20 employees, which includes microenterprises - based on the Hungarian interpretation of the concept - and a part of small enterprises. Moreover, in Sub-chapter 3.4 on payment discipline we also refer to data presented in the study entitled European Payment Report 2017 published by the international credit management company Intrum Justitia.

\subsection{Payment habits, applied payment methods, cash usage}

The findings of the 2017 survey indicate that credit transfer is by far the most widespread payment instrument among the ones (cash payments, credit transfer, card payments, other) examined in the supplier and customer relationships of Hungarian SMEs and microenterprises. This is followed by cash payments. Compared to these two payment methods, card payments are far less frequent, while other payment methods have all but disappeared from the supplier and customer relationships of SMEs and microenterprises (Figures 2 and 3). It should be noted that the question aimed at the applied payment methods offered nonexclusive response options as an enterprise may use multiple payment methods, although the frequency of using the respective methods can obviously be different.

\footnotetext{
${ }^{1}$ Her Majesty's Revenue and Customs
} 


\section{Figure 2 \\ Percentage of users of specific payment methods in supplier relationships}

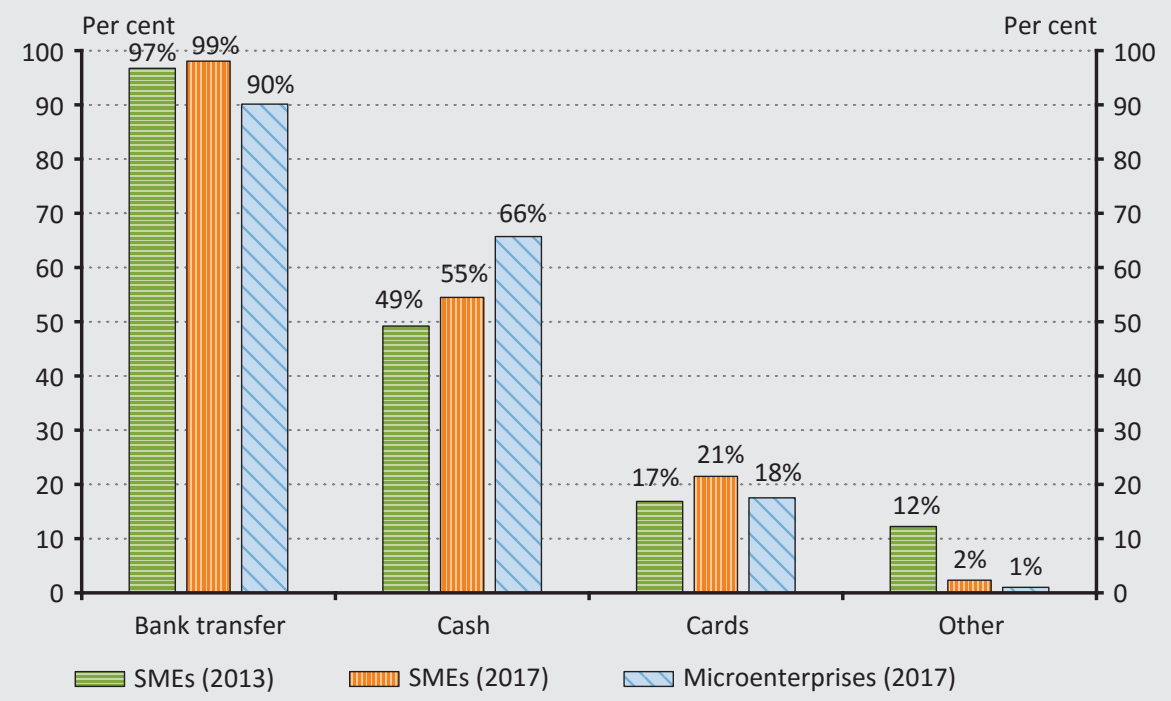

\section{Figure 3}

Percentage of users of specific payment methods in customer relationships

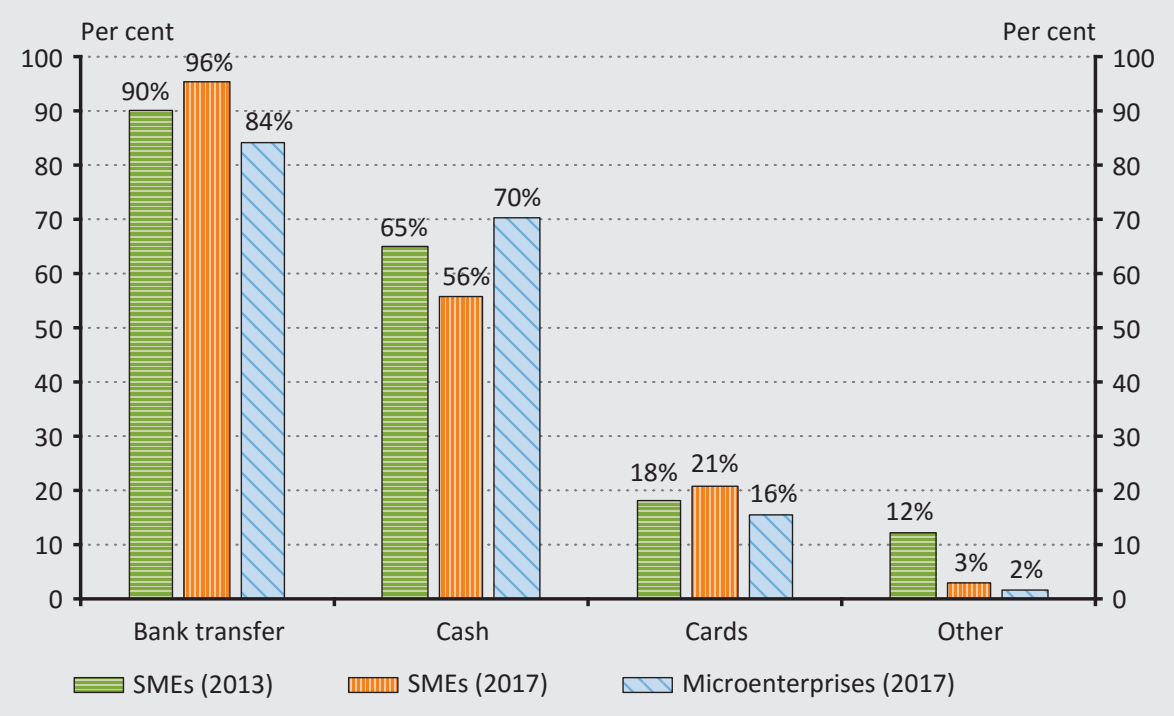


As regards credit transfers, we found that their prominence has increased further since 2013 and this payment method has become practically universal: nearly all enterprises initiate and receive credit transfers. 90 per cent of microenterprises rely on this payment method to fulfil their payment obligations, and 84 per cent of them also receive such payments.

Looking at cash payments, both on the purchase and on the sales sides users of cash payments are in the majority at SMEs and microenterprises alike compared to cashless enterprises. In the supplier relationships of SMEs, the percentage of cash users even increased somewhat compared to 2013 (to 55 per cent from 49 per cent), whereas in their customer relationships the rate of cash usage declined (to 56 per cent from 65 per cent). These changes are all the more remarkable considering as we will see later in the study - that customers' preference is among the most important motives of cash usage; in other words, a large number of enterprises justified their use of cash by the fact that some of their revenues are generated in cash. The percentage of cash-user enterprises is nearly the same on the customer and on the supplier sides (as a result of the reverse changes it currently stands at 56 and 55 per cent, respectively), which, however, suggests that the businesses whose cash revenues are generated on the customer side are more likely to use the cash to pay their suppliers than for making a cash deposit to their bank accounts.

The percentage of enterprises using business card ${ }^{2}$ payments is still extremely low, although it has edged up slightly since 2013 (although this growth is marginal, with a 95 per cent confidence level it can be considered significant). The percentage of card users is only 21 per cent among SMEs with no perceivable growth compared to 2013 , while microenterprises use this payment method at an even smaller rate (18 per cent). These rates are similarly low on the customer side: card payments are accepted only by 21 per cent of Hungarian SMEs and only by 16 per cent of microenterprises. Our data fall short of the 30 per cent acceptance rate presented in the Payment Systems Report published by the MNB (2018), mainly because the MNB's value is based on the 2016 OCR database, ${ }^{3}$ which predominantly includes retail stores and, to a lesser degree, restaurants and accommodations. The composition of acceptor enterprises by sector was not examined in the context of this survey, but we can deduce even from the core data that the percentage of acceptor enterprises - both in the case of SMEs and microenterprises - falls short of the combined percentage of enterprises which, based on their activity, belong to the sectors that are most likely to accept cards (trade, vehicle repair, catering, accommodation). ${ }^{4}$ This suggests that with regard to card acceptance, there is room for expansion even in these sectors.

\footnotetext{
${ }^{2}$ In the survey we did not distinguish between the use of credit cards and debit cards; we only focused on the use of business cards as a payment method.

${ }^{3}$ Online cash register database

${ }^{4}$ The composition of participating enterprises by sector is presented in Chapter 2.
} 
Based on the survey results, a large-scale decline can be observed in other payment methods and, at the same time, there was a pronounced change in the set of other payment methods identified by the respondents. While in 2013 a number of respondents still reported using letters of credit and collection orders as payment methods, in 2017 respondents typically identified vouchers, cash on delivery and "postal cheques" as other payment methods applied by the enterprise. ${ }^{5}$

Comparing our results to the abovementioned survey conducted in the United Kingdom ( $T u$ - Salmon 2016), we found that Hungarian enterprises lag behind their British peers mainly in the area of card usage: in the UK 42 per cent of the businesses under review allowed their customers to pay by bankcard (compared to 16 per cent observed in the case of Hungarian microenterprises), while only 67 per cent permitted credit transfers (whereas this rate in the case of Hungarian microenterprises is 84 per cent).

The prominence of specific payment methods can be not only examined in terms of the percentage of the enterprises applying them: we can also focus our attention on the rate at which the enterprises using the specific payment method rely on that method in fulfilling their payment obligations. The predominance of credit transfers can be clearly established from this perspective as well. As we have seen, nearly all SMEs (99 per cent) use credit transfers in their supplier relationships, but the survey results also demonstrated that the vast majority of the enterprises using credit transfers ( 83 per cent) fulfils $76-100$ per cent of their payment obligations using this payment instrument. From the perspective of customer relationships, we found that 96 per cent of SMEs use credit transfers for the receipt of incoming payments, and at least three quarters of incoming transactions are actually executed in this way at 76 per cent of the enterprises that use credit transfers. The survey indicates that the most widely used payment method among microenterprises is credit transfer: it is used by 90 per cent of the respondents, and 56 per cent of the users make at least three quarters of their payments in this way.

Although the majority of enterprises use cash both in their supplier and customer relationships, cash transactions affect only a smaller fraction of their payment transactions. Most cash-user SMEs (73 per cent) fulfil no more than 25 per cent of their payment obligations via cash payment, and even on the customer side, the enterprises that use cash payment in one quarter of their transactions at most are in the majority (62 per cent). The percentage of SMEs that predominantly use (in at least three quarters of their transactions) cash only was only 4 per cent on the supplier and 11 per cent on the customer side (Figures 4 and 5).

\footnotetext{
${ }^{5}$ The payment instrument referred to by respondents as "postal cheque" - whether they meant postal inpayment money orders or money orders - can be practically regarded cash payments, as is the case with cash on delivery as well.
} 


\section{Figure 4 \\ Cash payments in the supplier relationships of SMEs}

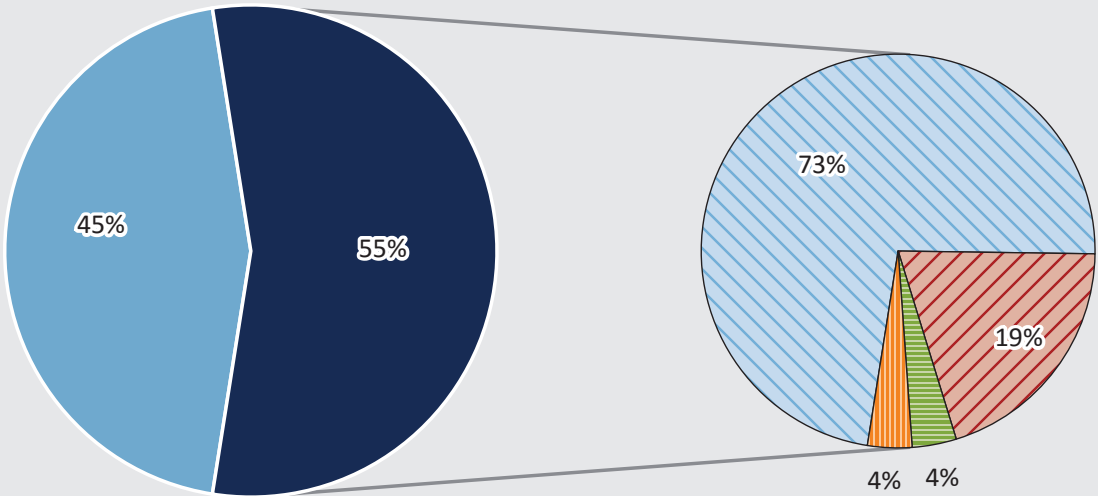

Uses cash

Uses cash for $0-25 \%$ of total payments

Does not use cash

$\square \backslash$ Uses cash for $26-50 \%$ of total payments

Uses cash for $51-75 \%$ of total payments

血血 Uses cash for $76-100 \%$ of total payments

\section{Figure 5}

Cash payments in the customer relationships of SMEs

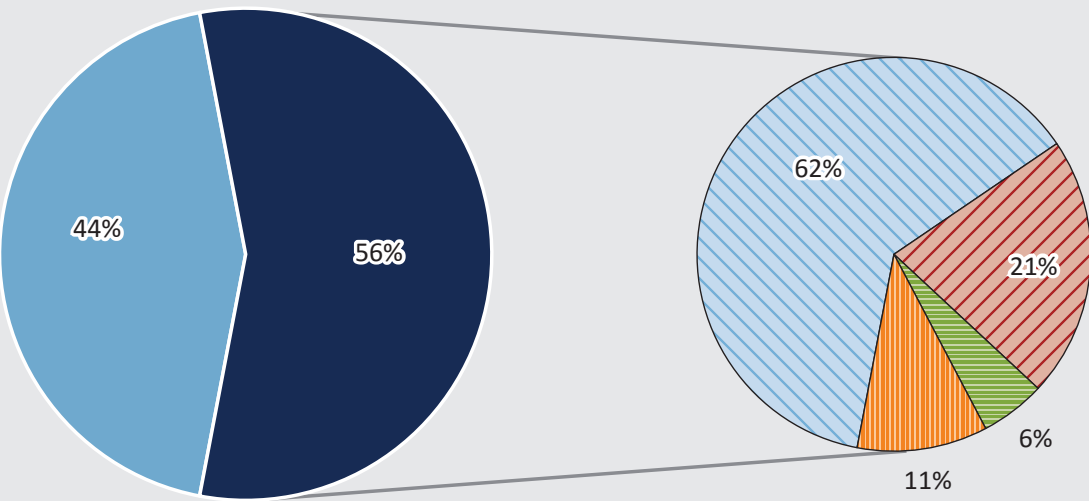

$\square$ Uses cash for 0-25\% of total payments

Does not use cash

$\mathrm{Z}$ Uses cash for $26-50 \%$ of total payments

Uses cash for $51-75 \%$ of total payments

Und Uses cash for $76-100 \%$ of total payments 
Cash payment is more widespread among microenterprises than among SMEs not only in terms of the percentage of cash users ( 66 per cent on the supplier side and 70 per cent on the customer side), but also in respect of those reporting a preference for cash transactions. Nearly one fifth of microenterprises fulfil at least three quarters of their payment obligations in cash, and 28 per cent of them also receive at least three quarters of their incoming payments in cash (Figures 6 and 7).

\section{Figure 6 \\ Cash payments in the supplier relationships of microenterprises}

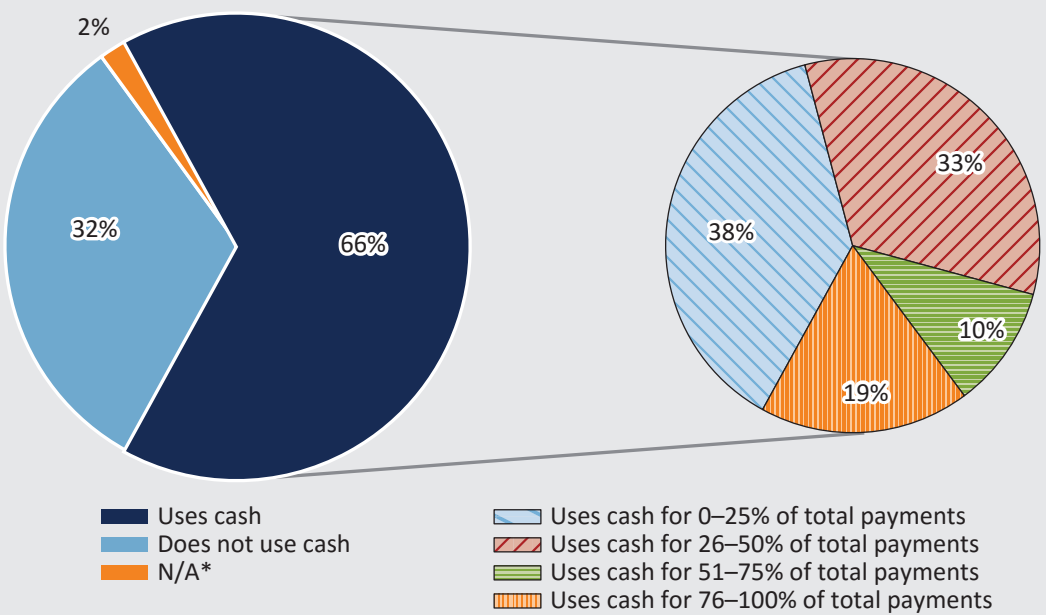

Note: * Do not know/did not answer.

\section{Figure 7}

Cash payments in the customer relationships of microenterprises

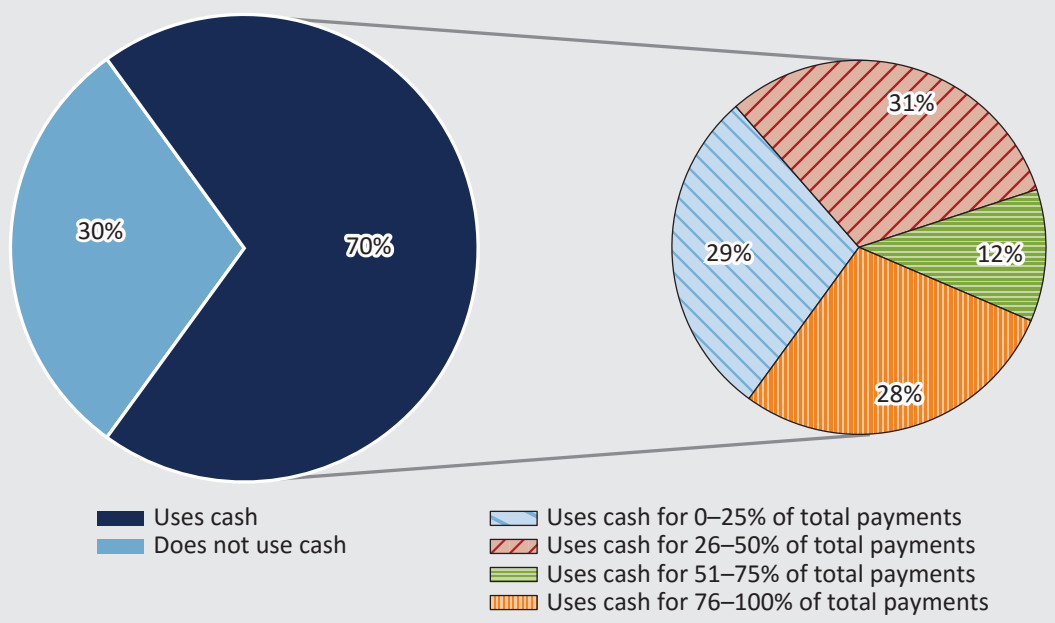


Compared to their British peers, Hungarian microenterprises typically do not rely on cash to a large degree in their customer relationships. While only 9.4 per cent of them handle all of their transactions in cash, in the UK 13 per cent of them refrain from using electronic payment methods altogether, typically in view of the significant costs involved. We can draw mixed conclusions regarding supplier relationships. 7 per cent of Hungarian microenterprises use exclusively cash in this dimension (compared to 19 per cent in the United Kingdom); at the same time, 54 per cent of British enterprises pay their suppliers via electronic means only, while this rate is only 32 per cent in Hungary.

Among SMEs, of the three payment methods under review respondents are the least likely to use bankcards ( 21 per cent only) and even they tend to resort to this method rather infrequently. The overwhelming majority (89 per cent) use bankcards for only 25 per cent of their payment transactions at most, and a significant portion (73 per cent) of the acceptors reported using card payment in no more than one quarter of the transactions. As is the case with SMEs, at microenterprises card payments play an ancillary role only.

Based on the results presented so far, we can conclude that cash usage still has a strong presence in the business relationships of the enterprises - more so in the case of microenterprises than at SMEs - and its rate has not changed significantly since 2013. While the frequency of cash payments can be considered secondary in comparison to credit transfers, its role is not negligible. Although credit transfers continued to increase their dominance in the past four years, there was no shift to cashless operation at SMEs and the presence of cash is particularly strong in the payments of microenterprises.

Since the focus of our study was essentially the cash usage of the enterprises, we specifically examined the average transaction value of cash payments both in the supplier relationships (outgoing payments) and in the customer relationships (incoming payments) (Figures 8 and 9). As illustrated by the figures, in both payment flows low-value (below HUF 50,000) transactions remained in the majority. Interestingly, however, compared to 2013 we observed a shift in the value of cash transactions towards larger amounts: there was a significant increase in both directions in the HUF $100,000-500,000$ category and in payments made to suppliers in the category of HUF 500,000 and above. Based on the in-depth interviews constituting a part of our research, the reason for the phenomenon, presumably, is the financial transaction levy introduced in 2013, which is typically passed on to customers by the financial institutions. In addition, our observations also support our previously mentioned assumption, namely, that Hungarian firms are more likely to use the incomes generated in cash for paying their suppliers (even in the case of higher-value purchases) than for making a cash deposit to their payment accounts. 


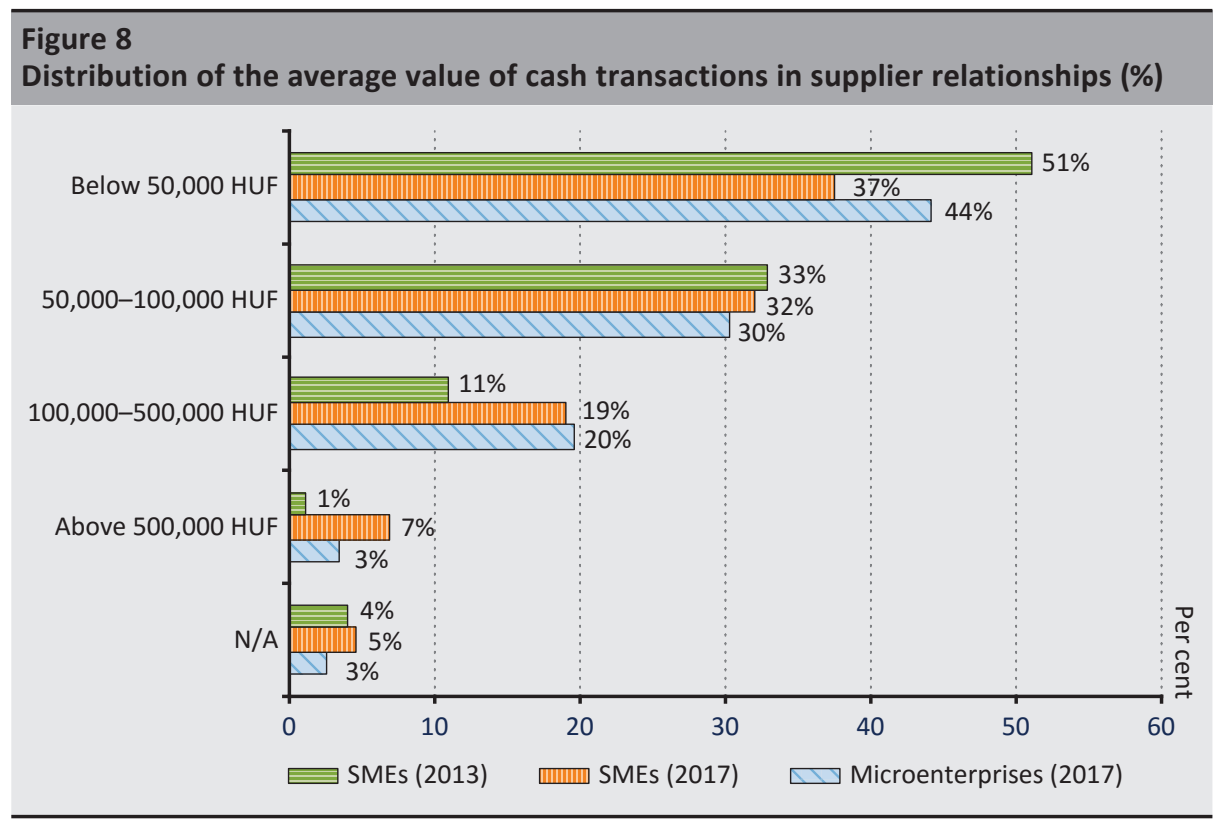

\section{Figure 9 \\ Distribution of the average value of cash transactions in customer relationships (\%)}

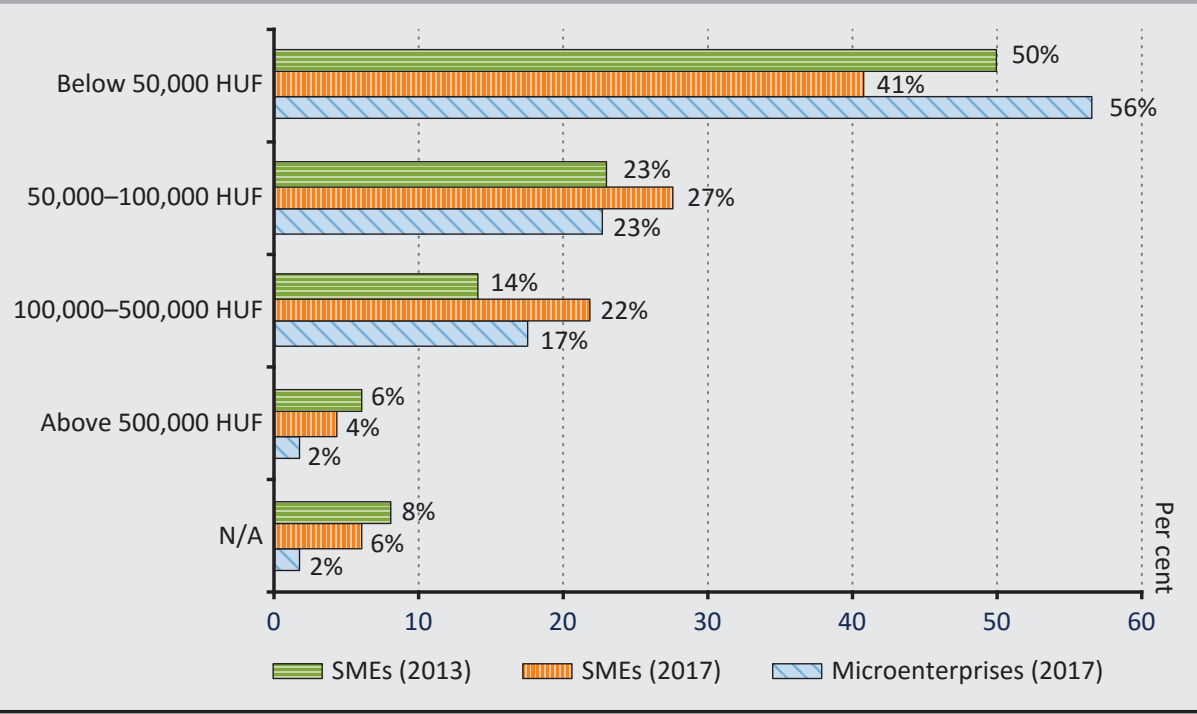


In addition to the payment methods applied in supplier and customer relationships, in the 2017 survey we also asked enterprises to identify the payment methods they typically use for paying their utility bills (Figures 10 and 11). Respondents were asked to reveal whether they used any of the payment methods listed in the questionnaire (cash, postal inpayment money order, ${ }^{6}$ credit transfer, direct debit). Since enterprises can pay individual utility bills in various ways, a respondent could obviously indicate multiple payment methods. On the charts, "cash" indicates the percentage of enterprises making direct cash payments at the customer service offices of the public utility company, while "postal inpayment money order" shows the percentage of enterprises making payments (for example, in post offices) with "yellow cheques".

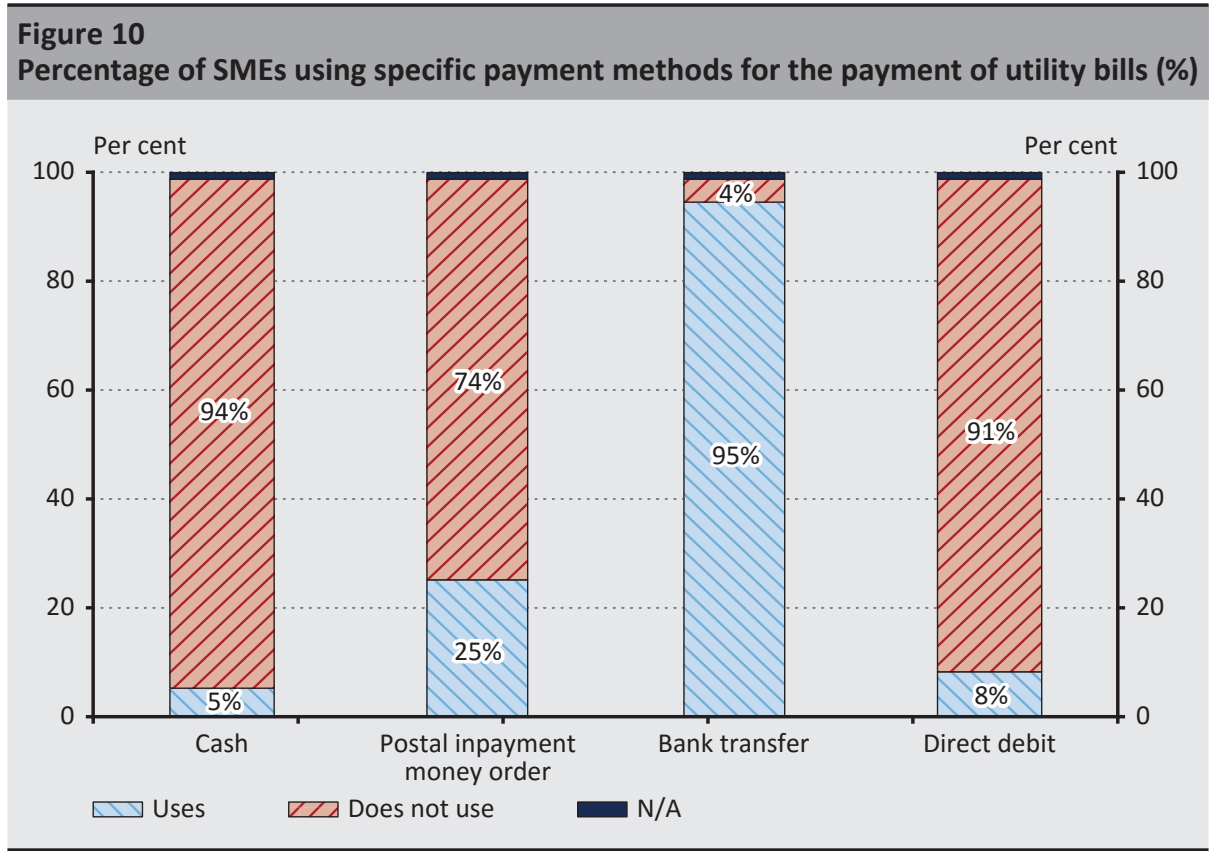

${ }^{6}$ The so-called "yellow cheque" 


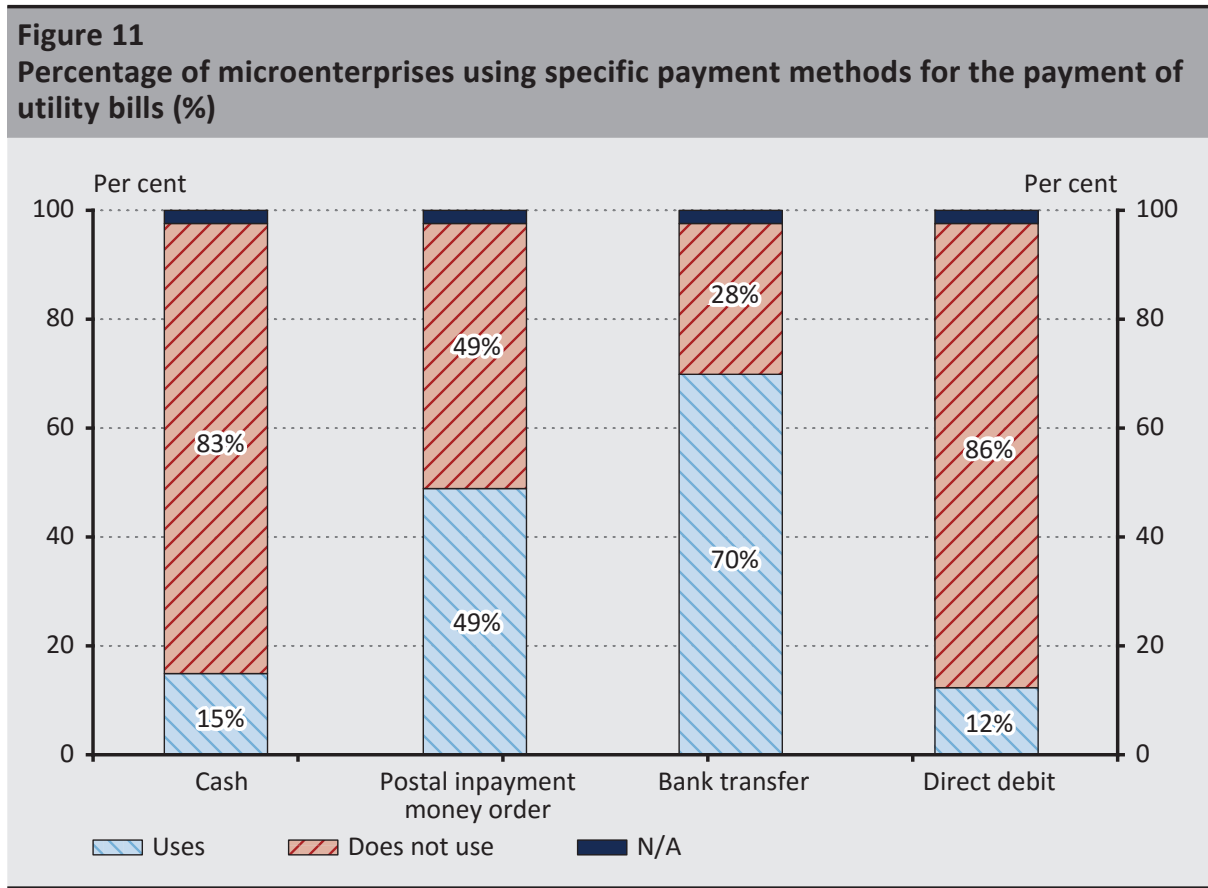

Most respondents reported using credit transfer for the payment of utility bills as well, but cash payments ${ }^{7}$ are also popular. Postal inpayment money orders are applied by one quarter of SMEs and by one half of microenterprises, but 5 per cent of SMEs and 15 per cent of microenterprises also use direct cash payments. In this context, our most striking finding concerns the use of direct debit, which is designed specifically for the fulfilment of such payment obligations as utility bills, but an extremely low number of enterprises use this payment option (8 per cent of SMEs and 12 per cent of microenterprises).

Besides suppliers and utility bills, wages imply a regular payment obligation for enterprises. Therefore, our survey was also intended to gauge the rates at which wages are paid in cash and credit transfer (Figure 12). The question only covered compensation regularly paid in monetary forms; any other benefits (such as meal vouchers) were excluded from the survey.

Based on the replies, we classified the enterprises into 5 groups depending on the rate at which they paid salaries in cash. ${ }^{8}$ The most typical form of wage payment was credit transfer both among SMEs and microenterprises: nearly 60 per cent of SMES

\footnotetext{
${ }^{7}$ Although nowadays postal inpayment money orders can be paid by card, in view of the enterprises' low propensity to use cards in supplier relationships we typically consider them to be a form of cash payment. ${ }^{8} 0 \%$ : "Exclusively via credit transfer"; 1-49\%: "Mainly via credit transfer"; 50\%: "At the same rate"; $51-99 \%$ : "Mainly in cash"; and 100\%: "Exclusively in cash".
} 
and more than 40 per cent of microenterprises reported paying their employees exclusively via credit transfer. However, while the number of respondents belonging to the groups that have an increasing percentage of cash-based wage payments is continuously decreasing among SMEs and the percentage of those not using credit transfer for this purpose at all is only 5 per cent, a significant portion - 36 per cent - of the participating microenterprises reported paying their employees fully in cash. It should be also stressed that according to our survey, around 50 per cent of the microenterprises pay at least half of their employees' wages in cash, the same percentage is far smaller - 23 per cent - among SMEs. Consequently, we may adjust our initial assumption - especially in the case of microenterprises - to the effect that enterprises use the cash inflows from their customers mainly for fulfilling payment obligations towards their suppliers but also, to a non-negligible degree, for paying their employees. Cash payments to employees clearly represent a factor generating cash transactions, as employees drawing their income in cash will obviously settle their household expenses in cash.

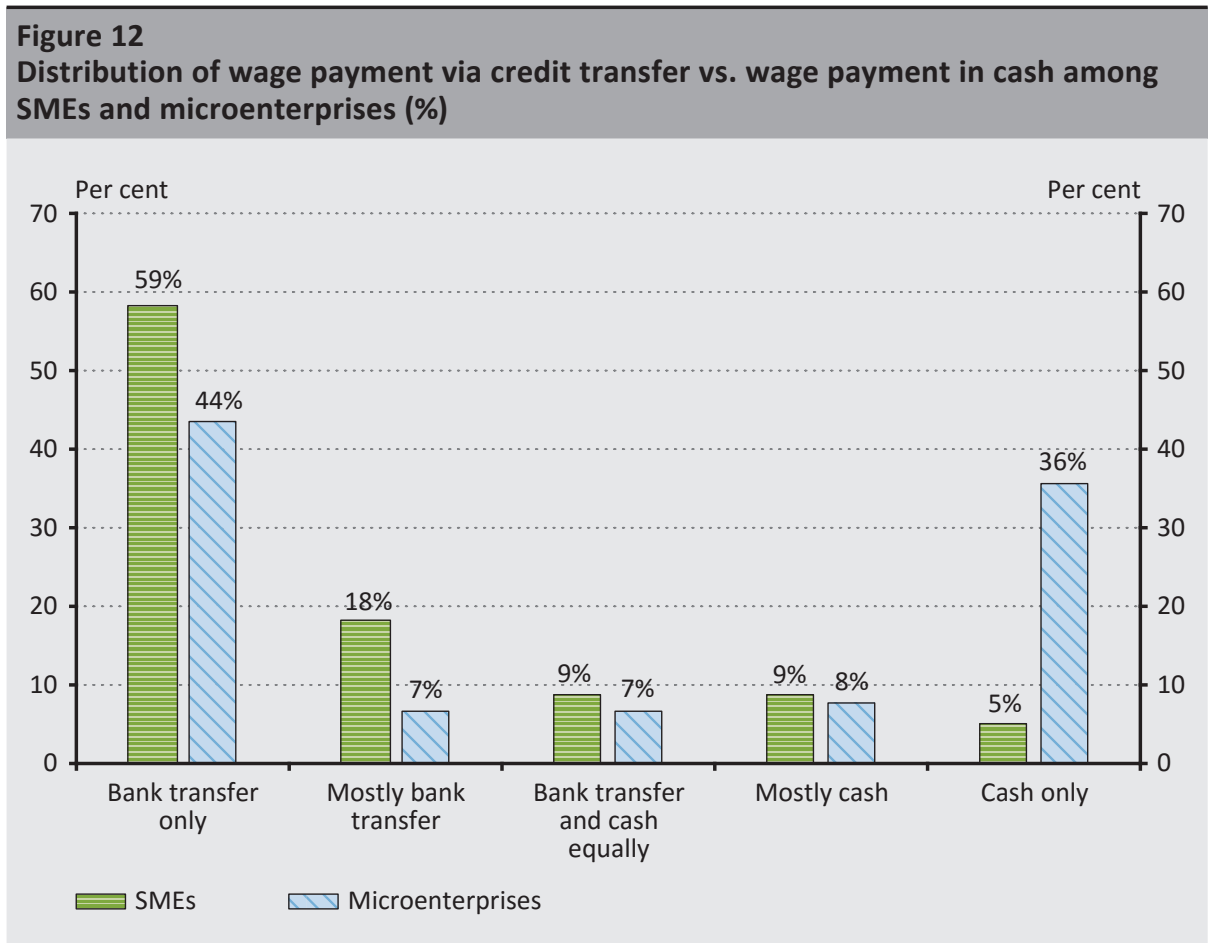


We can conclude that Hungarian microenterprises tend to use cash to pay wages at a fairly high rate by international standards; indeed, according to the British data referred to above, 64 per cent of the enterprises fully settle their wage costs via credit transfer in the UK, whereas the percentage of those using cash exclusively was only 23 per cent.

\subsection{Impact of regulatory measures on the payment habits of enterprises}

The 2013 survey also asked whether the adoption of certain administrative, regulatory measures affecting payment transactions had an impact on the cash transactions of participating SMEs and if yes, in what direction. That survey found that none of the measures under review (intraday transactions, the cap on B2B cash payments and the financial transaction levy) caused significant changes in the payment practice of the enterprises, and the responses given with regard to the aggregate effect of the measures also indicated that the measures had no substantial effect on the SMEs cash transaction totals neither in terms of outflows or inflows. These findings were also confirmed by the research of Ilyés et al. (2014) on the features of corporate and household payment transactions. However, since the 2013 survey was taken shortly after the introduction of the measures and the regulation on the financial transaction levy had even changed in the meantime, in our 2017 research we once again asked SME respondents about the potential effects of the two measures (intraday transactions and financial transaction levy) on payments.

The findings of the 2017 survey regarding the effect of intraday transactions on cash usage were mixed: on the one hand, compared to 2013 the percentage of enterprises reporting a perceivable effect of the availability of intraday transactions on their own operation declined significantly (from 87 per cent to 56 per cent); on the other hand, however, the rate of those being able to replace some of their cash transactions by electronic credit transfers thanks to the availability of intraday transactions increased overall (they accounted for only 11 per cent of the respondents perceiving the effect of intraday transactions in 2013 compared to 48 per cent in 2017 which, projected to the whole sample translated into 10 per cent of the enterprises in 2013 and covers 27 per cent of them in 2017). These results suggest that a large number of the enterprises now perceive intraday transactions as a natural part of credit transfers; consequently, they no longer regard them as a special benefit. At the same time, it is clear that enhancements in the area of electronic payments have a direct impact on the retrenchment of cash usage among enterprises, which is reconfirmed by the responses given to our questions about the incentives for the reduction of cash usage (see Sub-chapter 3.6). 
As regards the financial transaction levy, in the current survey the enterprises were somewhat more likely to report that the financial transaction levy had no effect on the payment practice of their enterprise ( 73 per cent in 2017 vs. 68 per cent in 2013). The majority (70 per cent) of those perceiving a change in the enterprise's payment practice, commonly apply the procedure of consolidating individual electronic payment transactions to their partners in order to reach the upper limit of the levy. Only a smaller percentage (15 and 16 per cent) of the enterprises reported an increase in outgoing and incoming cash payments, which covers only 4 per cent of the enterprises included in the total sample.

\subsection{Motivations of cash usage}

Businesses are required to have a payment account. Contrary to the population, therefore, access to banking services and the existence of bank relations are inevitable in their case. What motivates, then, enterprises to pay their suppliers in cash at the rate observed during the survey, or to accept cash payments? In the quantitative survey, respondents were most likely to identify low value and their customers' preference as the main motive behind the use of cash (Figures 13 and 14). ${ }^{9}$

\section{Figure 13 \\ Reasons for cash usage in the supplier and customer relationships of SMEs (\%)}

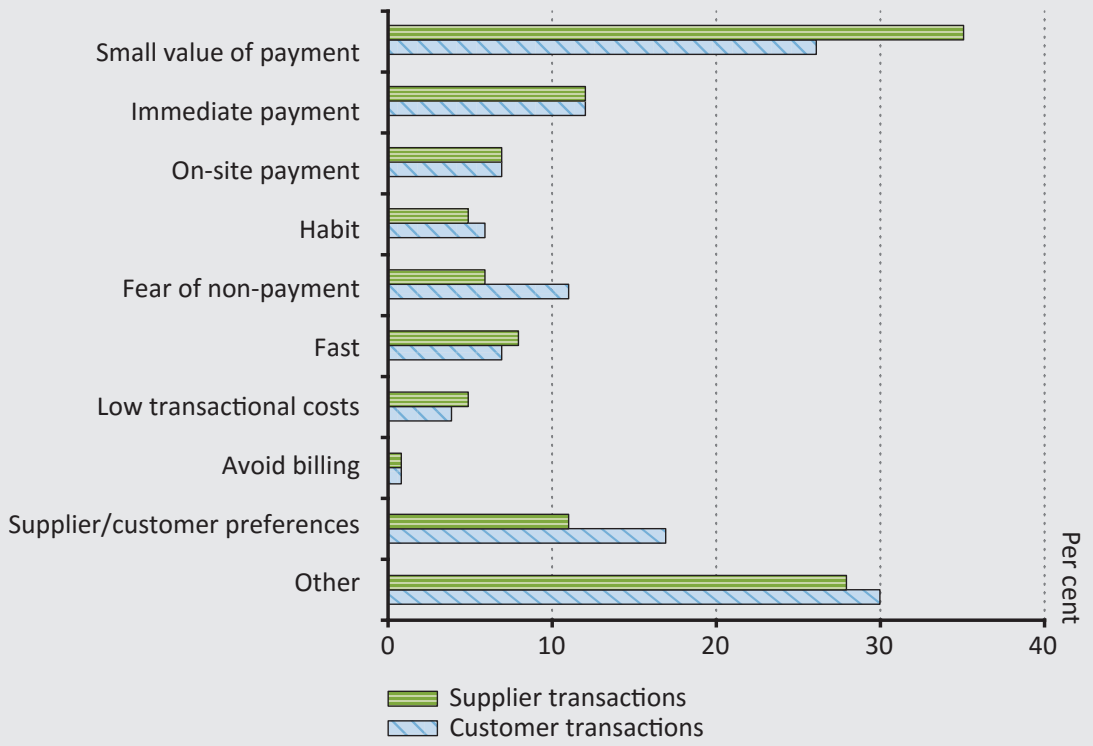

\footnotetext{
${ }^{9}$ Respondents were allowed to indicate several reasons for their cash usage. Since the motives listed were slightly different in the 2013 and 2017 surveys, the results are not fully comparable; therefore, the results received in 2013 were not displayed in the summary figure.
} 


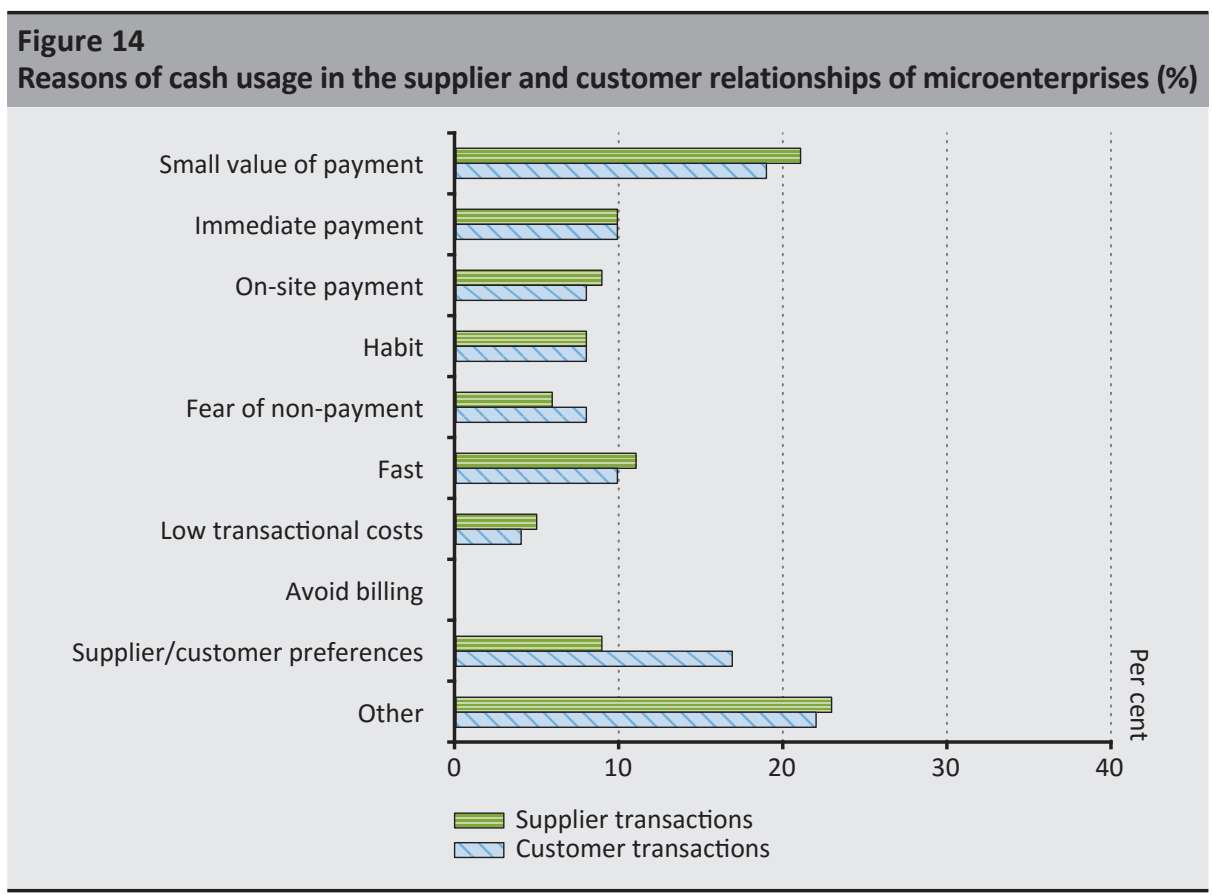

We should note that besides the reasons on the original list, a high percentage of the respondents indicated the "other" category as the motive behind the use of cash. Those selecting the "other" category frequently mentioned, albeit in different words, reasons that can be classified into customer preference (e.g. "private individuals tend to pay in cash", "many customers have no cards"). This indicates that customers' need to use cash is much stronger in reality - especially among retail customers - than the value calculated for customer preference. Customer preference deserves special attention because the cash received by enterprises regularly or continuously from - typically retail - customers may have a spillover effect; indeed, cash revenues are spent - at least in part - on some of the purchases of the enterprise, and the supplier may also use this cash revenue to pay for its own purchases. This could explain the increase in the percentage of enterprises that use cash in supplier relationships and also the rise in the average value of suppliers' cash transactions. The other reasons most cited by respondents - in addition to those belonging to the customer preference category - were simplicity, convenience and the ease of making ad hoc purchases.

It should be pointed out that even though relatively few respondents selected the fear of non-payment from the original list (11 per cent of SMEs and 8 per cent of microenterprises in their customer relationships), quite a few respondents chose uncertainty and distrust from the other reasons that may motivate them to use cash. Even so, a substantial change can be observed in this regard compared to the 
result of the 2013 survey: in 2013, 26 per cent of the respondent SMEs reported using cash because of concerns about their customers' non-payment. This can be interpreted as a significant, positive improvement in fair business conduct and trust between enterprises.

Similarly, habit as a motive for cash usage has noticeably weakened since 2013. While at the time of the 2013 survey 18 per cent of SMEs reported using cash out of habit, by 2017 this rate dropped to 5 per cent in the supplier relationships of SMEs and to 6 per cent in their customer relationships, but even among microenterprises this value is only 8 per cent in both payment directions. Although only a negligible fraction of the enterprises cited the avoidance of invoicing (and hence, anonymity) as the reason behind cash usage, the real rate may be higher than that as, even anonymously, respondents are presumably reluctant to reveal their own unlawful conduct.

Although the incentives for the retrenchment of cash payments will be discussed later in the study, at this point we should nevertheless mention two factors. A large number of respondents revealed - both SMEs and microenterprises - that a decline in the costs of electronic payment solutions and the expansion and increased flexibility of electronic banking services would be the strongest incentives for scaling back their cash usage (they were most likely to select these two incentives of those listed in the questionnaire). These results indicate that cash-user Hungarian enterprises are remarkably open to electronic payment solutions, which is a large step forward compared to 2013. Based on the evaluation of the status observed at the time of our survey, we can conclude that the selection of electronic banking services currently provided by credit institutions is insufficient to cover and/or unable to meet the demand arising from the side of enterprises. The reduction of this gap could generate a robust shift towards cashless enterprises even in a matter of a few years.

\subsection{Trust (distrust), uncertainty, payment discipline}

The 2013 survey focused on the trust - or lack thereof - in the B2B relationships of SMEs and on the correlation between payment behaviour and the motives of cash usage. The results indicated that enterprises were acutely aware of the lack of trust or more precisely, their partners' unreliability, which essentially stemmed from the uncertainty surrounding the post-crisis economic environment. The greatest problems were caused by weak payment discipline and the general practice of late (overdue) payments. In order to mitigate the risks arising from late payments and potential non-payments, enterprises curtailed their payment deadlines and routinely demanded instant or even advance cash payments. In preparing for the 2017 survey, the question arose whether this situation had changed after the end of the crisis; therefore, we once again examined the potential correlation between 
payment discipline (payment terms, overdue receivables or bad debt losses) and cash usage.

Payment terms may have great economic significance, as small and medium-sized enterprises may often take advantage of longer payment deadlines consistently in order to gain access to liquidity, especially if they have no access to other financing channels, such as short-term bank loans. ${ }^{10}$ This phenomenon was simulated by Burkart and Ellingsen (2004), on the basis of which Havran et al. (2017) empirically demonstrated that on a sample of Hungarian firms a complementary effect could be observed between short-term bank loans and accounts payable in the period of 2010-2015. Moreover, analysing the data of SMEs across 13 European countries over the period of 2003-2012, McGuiness et al. (2017) found that enterprises with access to trade credit were less likely to face financial distress during the credit crunch of the economic crisis. With relaxed payment terms, therefore, enterprises with ample liquidity may be able to assist distressed or temporarily insolvent firms. Consequently, we may conclude that it would be desirable in Hungary, as well, if the SME sector relaxed payment terms which, according to the 2013 survey, can be considered rather tight.

However, compared to 2013, we did not find any noticeable change in the payment terms typically applied by enterprises. Most enterprises (44 per cent of both SMEs and microenterprises) are expected by their suppliers to pay within 8-30 days and similarly, most of them ( 38 per cent of SMEs and 40 per cent of microenterprises) also impose such payment terms on their customers (Figures 15 and 16). While SMEs' leeway increased on the supplier side (based on the sample, the percentage of those receiving a deadline of 30, 30-60 and 60-90 days increased somewhat), at a confidence level of 95 per cent only the latter can be considered significant. Only a small fraction of this is passed on to customers; a significant increase can only be observed among those with a 30-day deadline.

A moderate improvement can be observed in the area of instant, simultaneous payment. Albeit slightly, the percentage of SMEs requiring instant payment declined significantly (to 8 per cent from 12 per cent in 2013); however, a high ratio of microenterprises (20 per cent) still demand instant payment from their customers. Since - as we could see - few enterprises use card payment and only seldom at that, we have reason to assume that a large part of instant payments are made in cash.

${ }^{10}$ The international literature refers to this type of financing as "trade credit". 


\section{Figure 15}

Typically applied payment terms in supplier relationships (\%)

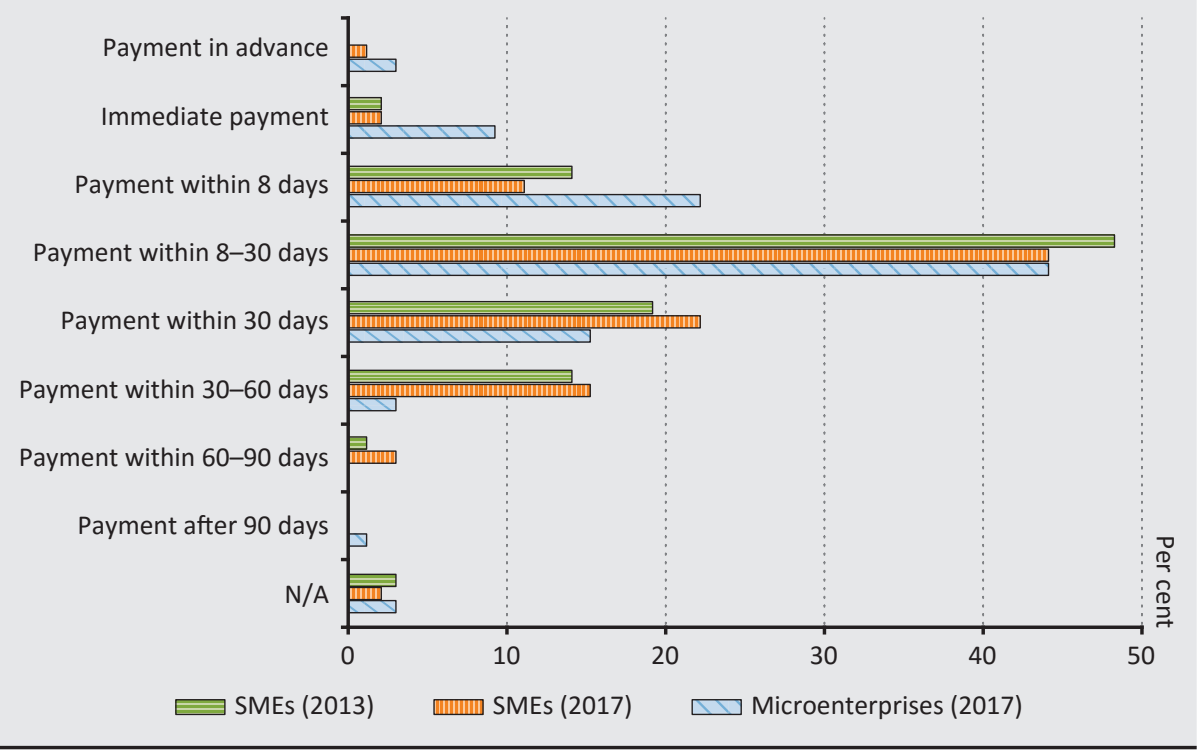

\section{Figure 16}

Typically applied payment terms in customer relationships (\%)

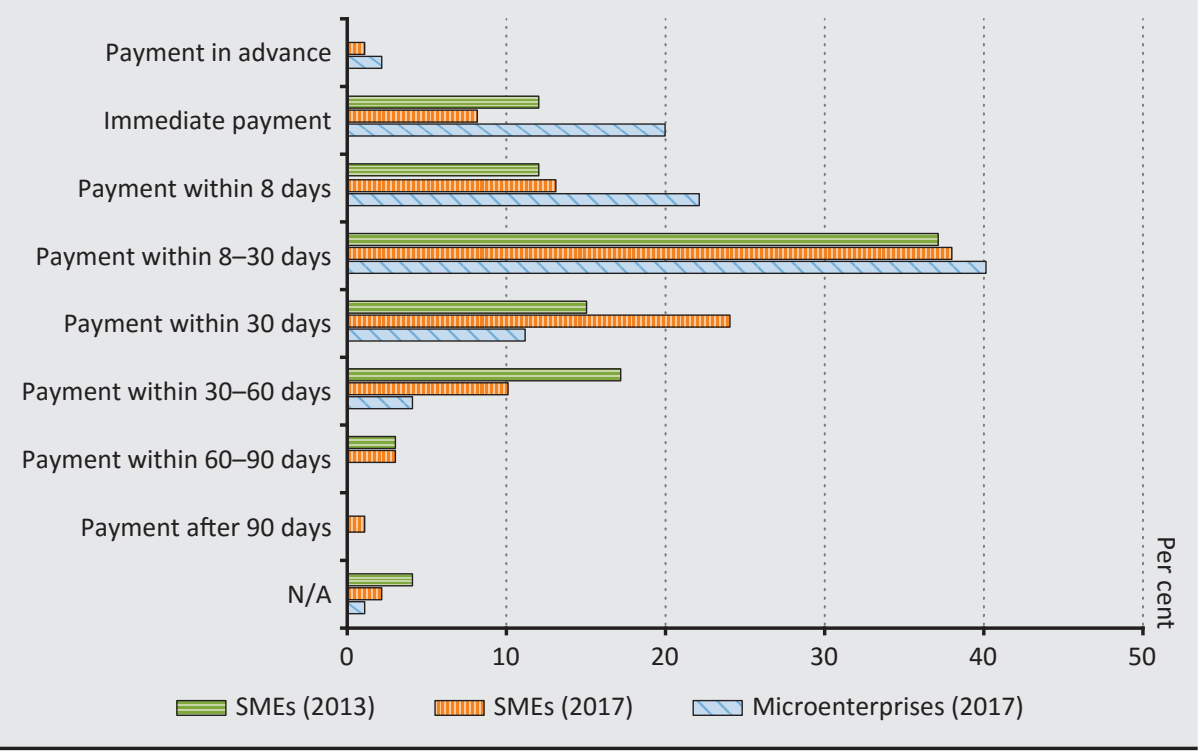


As demonstrated by the figures, microenterprises face much tighter payment terms in their supplier relationships than SMEs and not surprisingly, they also tend to impose shorter deadlines on their customers. Since the result of the analysis of overdue receivables or bad debts does not justify this kind of discrimination, the tighter payment terms imposed by suppliers on microenterprises are more likely related to their weaker bargaining position than distrust in their willingness to pay.

Microenterprises were less likely than SMEs to report that they currently have overdue accounts payable (10 per cent of microenterprises vs. 21 per cent of SMEs). Examined from the customer side, overdue receivables or bad debts show a more unfavourable picture (60 per cent of SMEs had overdue receivables and 48 per cent incurred bad debt losses over the past three years; in the case of microenterprises these rates are 28 and 31 per cent, respectively). Based on this, we may assume that respondents may have painted a more favourable picture of their own payment behaviour than would be realistic, but this phenomenon may have occurred in both enterprise groups and accordingly, we have no reason to assume that SMEs are more reliable in performing their payment obligations than microenterprises.

Comparing the 2013 survey to the data from the current study (Figure 17), we found that the responses to the questions in relation to overdue receivables or bad debts clearly point to an improvement in payment discipline in the SME sector. While nearly half of the respondents had overdue receivables in 2013, by 2017 this rate had dropped to less than 20 per cent, and the decline was particularly pronounced in the case of low-value debts (below HUF 1 million).

The answers to the questions concerning bad debt losses also confirm the improvement in payment discipline. Owing to scaling differences, the value of the receivables in 2013 vs. 2017 cannot be compared directly, but we can establish that half of the respondents in 2017 had not faced irrecoverable debts during the past 3 years, compared to 35 per cent in 2013 (Figure 18).

Summing up the responses relating to compliance with payment terms and the amount and magnitude of outstanding receivables and bad debts, we can conclude that the business environment and hence the payment discipline of enterprises has improved significantly in the SME sector. This shift is extremely important for operability and competitiveness, as it may pave the way for corporate growth through improvement in enterprises' operating and liquidity conditions. 


\section{Figure 17}

Value of overdue receivables in 2013 and 2017 among SMEs

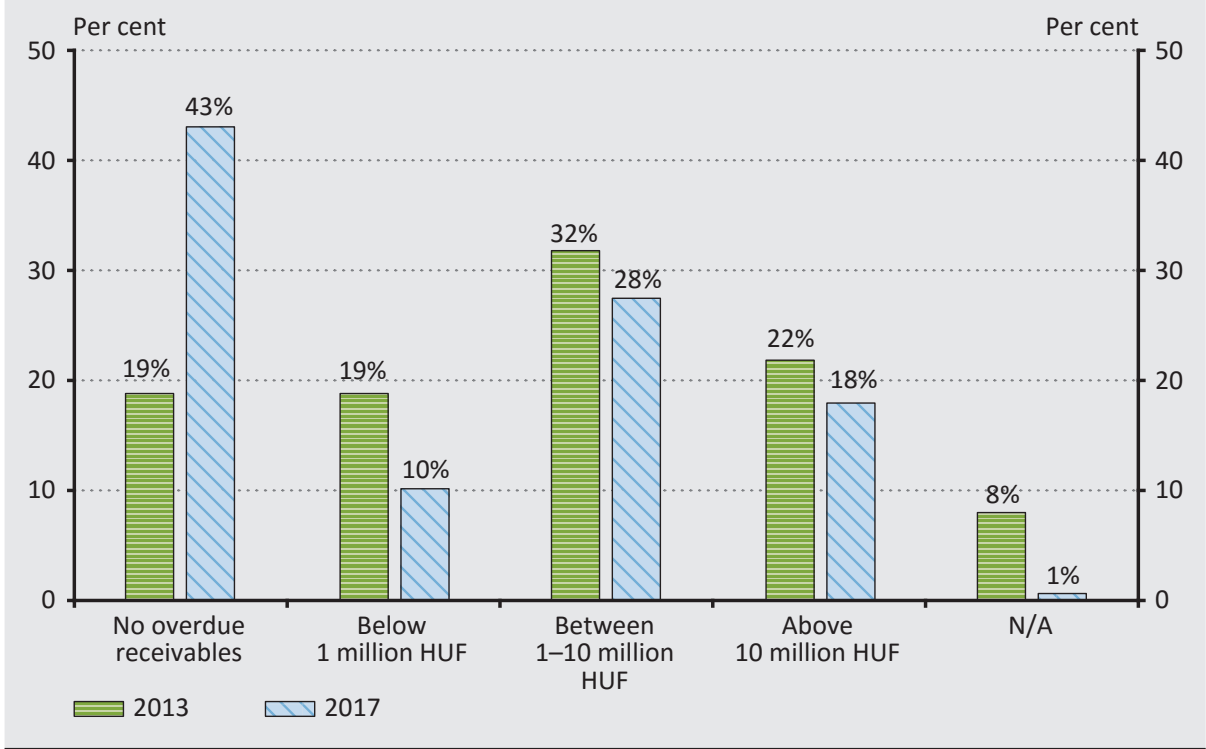

\section{Figure 18}

Did the enterprise have bad debt losses in the past 3 years? SMEs replies in 2013 vs. 2017

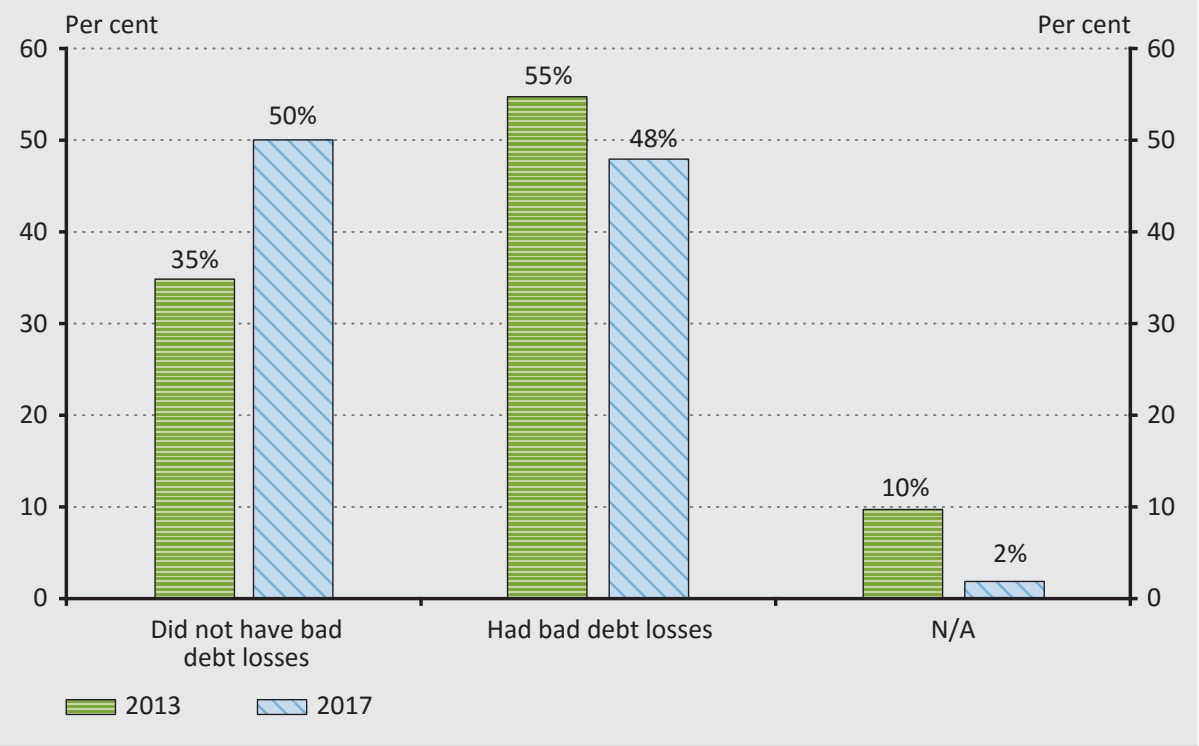


According to the study entitled European Payment Report 2017 published by the international credit management company Intrum Justitia, payment discipline in Hungary is good, overall, by international standards. Although with 29 participating European countries, their survey not only covered micro, small and medium-sized enterprises, we can still draw important conclusions from its results. According to their Report, average payment terms for B2B transactions are 26-27 days and 11-14 days in business-to-customer (B2C) transactions. These values in the public sector are somewhat more favourable - 27 days - than the European average. Hungarian businesses are forced to write off 2.1 per cent of their annual revenues as bad debt loss, which corresponds precisely to the rate calculated for Europe as a whole.

The most important findings of the study relevant to Hungary can be summed up as follows. It is a generally accepted practice in Hungary among businesses to accept longer-than-ideal payment terms at the request of their customers. 58 per cent of the respondents agree to ease payment terms unconditionally, and this rate is expressly high by European standards. The most common cause for late payments lies in the debtor's financial difficulties. Disputes over settlement or administrative inefficiencies are less common in Hungary. Around 40 per cent of the respondents indicated that late payments curtail company growth to some degree, and 24 per cent thought that faster payments from customers would enable their company to hire more employees.

It can be stated, overall, that the degree of distrust currently present in the Hungarian corporate sector does not exceed the European average; in fact, some indicators lead us to conclude that Hungarian enterprises trust their customers to a higher-than-average degree. Based on our survey, while average payment terms eased only slightly, the share of both late payments and bad debts shows a declining trend All things considered, the view that the main motive behind the still substantial cash usage of Hungarian SMEs and microenterprises is a general sense of distrust appears no longer true in 2017.

\subsection{Credit institution preferences, bank switching}

Our survey also sought to explore the considerations on the basis of which Hungarian businesses choose their account manager financial institutions, whether they switched banks in the past 3 years and if yes, why. The primary purpose of this exercise was to examine whether dissatisfaction with banking services and the associated costs were among the underlying reasons for cash usage.

According to our results, participating enterprises are extremely loyal to their account manager financial institutions, as only around 15 per cent of them switched banks in the past few years. This rate is roughly the same for SMEs and microenterprises. The primary reasons for the switch for SMEs were cost efficiency, or a more convenient service better tailored to their specific needs and 
the availability of a more favourable service package (e.g. account management conditions, borrowing). Nearly half (46 per cent) of those switching banks over the past 3 years were motivated by the former, and around a third of them ( 30 per cent) by the latter criterion in the switch. To a smaller degree, dissatisfaction with the previous financial institution was also cited as the reason for the switch, and a non-negligible percentage of the respondents were forced to switch banks because of the bank's liquidation or bankruptcy.

Microenterprises also reported that the main reason behind the switch was cost efficiency, or better service combined with a more favourable financial service package; however, the respective rates fall behind those observed among SMEs in the case of both reasons (33 per cent and 22 per cent, respectively). Forced switches due to the bankruptcy or liquidation of the previous financial institution, however, were cited by a higher percentage of the respondents compared to SMEs (20 per cent), and another important factor in their case was the proximity of branches. 11 per cent of the microenterprises switching banks in the past 3 years justified the switch by the shutdown of the nearest branch of the previous account manager financial institution (Figures 19 and 20).

\section{Figure 19}

Percentage of SMEs switching account manager banks in the past 1-3 years and the main reason for the switch (\%)

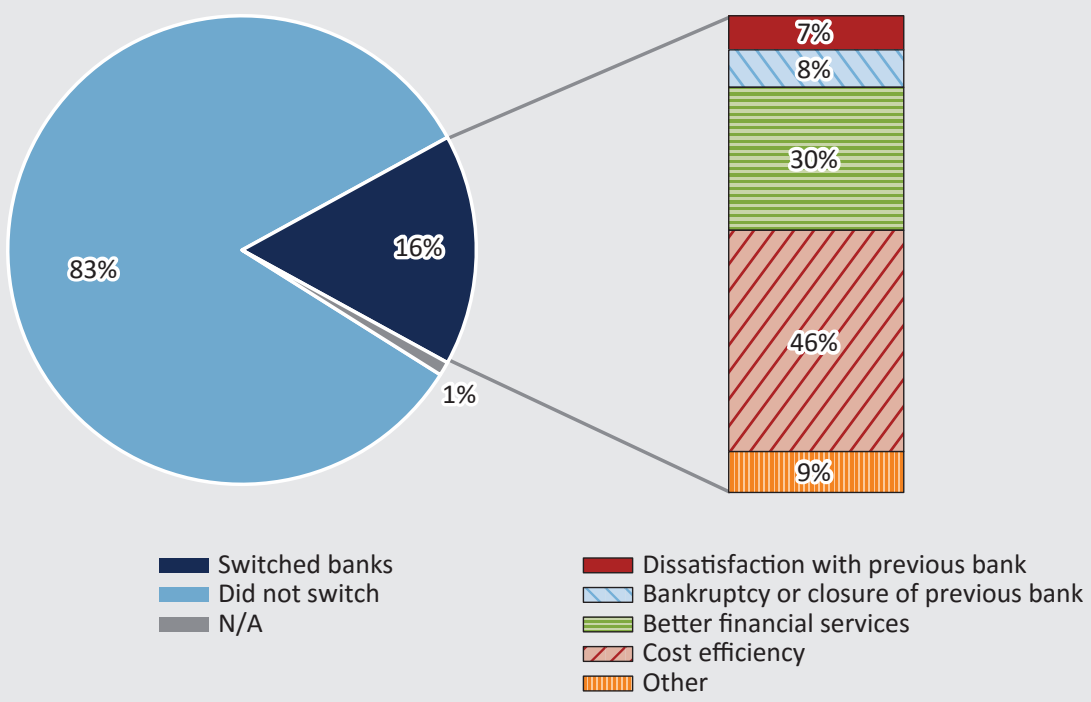




\section{Figure 20}

Percentage of microenterprises switching account manager banks in the past 1-3 years and the main reason of the switch (\%)
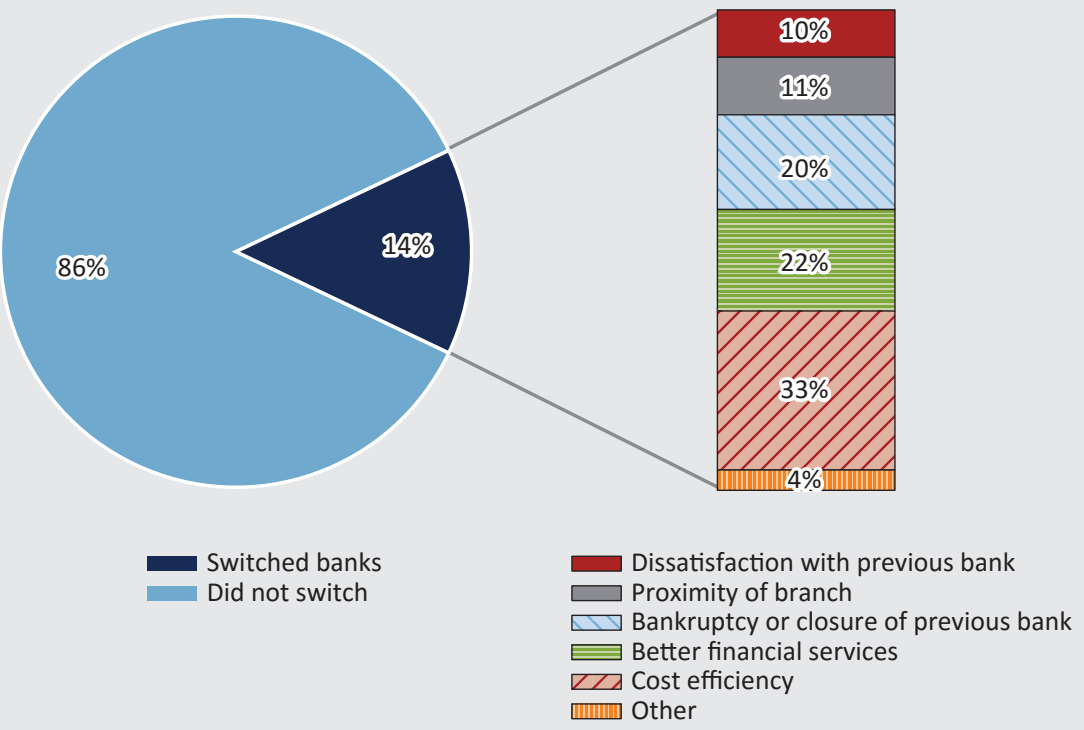

We also asked participants to indicate the secondary reasons for the switch, without limiting the number of answers that could be given. Around half of the respondents cited at least one secondary reason among both SMEs and microenterprises. In both cases, respondents typically mentioned personalised service and the availability of a more favourable service package. In addition, they also cited cost-efficiency, dissatisfaction with the previous account manager and easier access to the branch of the new bank (proximity, opening hours).

Aggregating the answers given to these two questions reveals the percentage of enterprises whose decision was motivated by the respective consideration (Figure 21). Based on our results we found, overall, that the most typical motivations for switching banks were cost efficiency, personalised service or a more favourable financial service package. These considerations are more important for SMEs; accordingly, around 60 per cent of SMEs and 40 per cent of microenterprises reported that these aspects played a role in their decision. It should be noted that, based on the replies, bank switching was associated with dissatisfaction with the previous financial institution in only about 20 per cent of the cases. 17 of 80 respondents switching banks identified this as either the primary, or the secondary reason in the case of SMEs, while the corresponding rates among microenterprises were 72 and 13 per cent, respectively. Microenterprises were more likely to indicate proximity and access to branches as the reason for switching banks: 21 per cent of the relevant respondents were motivated by these considerations. 


\section{Figure 21 \\ Percentage of respondents considering the given criterion among those switching banks in the past $1-3$ years $(\%)$}

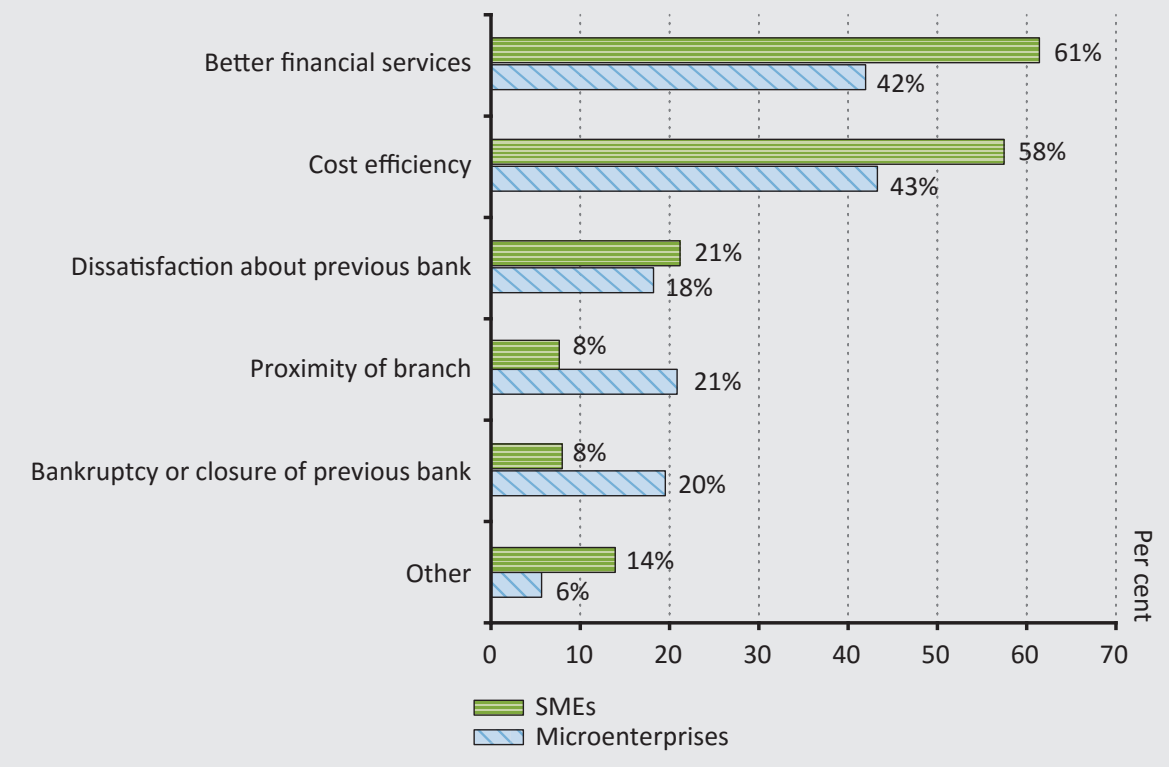

The bank selection preferences of the enterprises were examined with the assistance of another question, where respondents were asked to pick two statements out of five with which they agree most regarding access to branches (Figure 22). The most popular statement among both SMEs and microenterprises was the one that said "I only choose a financial institution that has a branch near my registered office/site". 45 per cent of microenterprises picked this statement compared to a slightly lower percentage of SMEs (35 per cent), which confirms our previous assumption that proximity to branches is a more important consideration for microenterprises. This assumption is supported further by the fact that 12 per cent of SMEs are willing to choose a more distant branch in exchange for better fees or conditions, while this rate is only 8 per cent among microenterprises. 


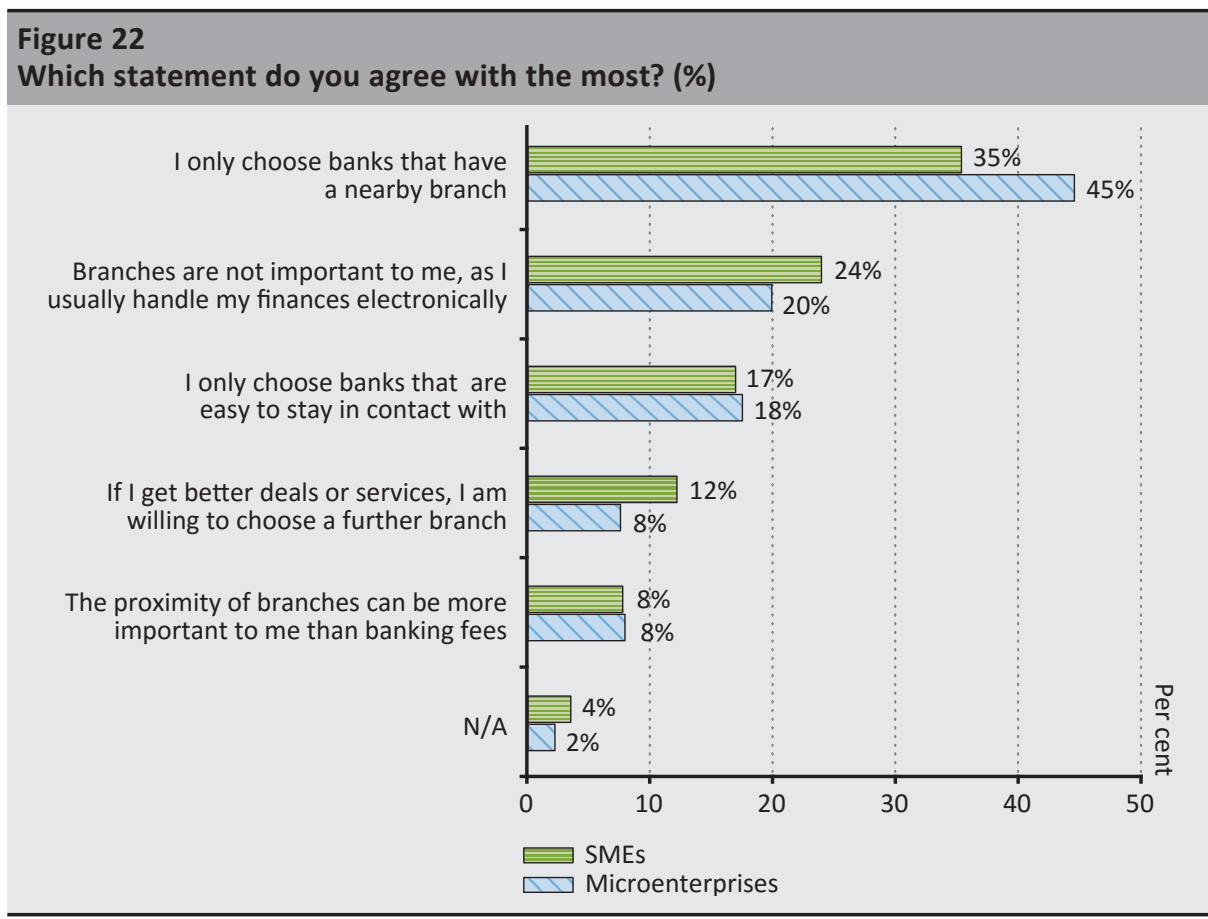

8 per cent of the respondents of both types of enterprises considered access to branches critical, and were even willing to pay higher account management fees in return. A higher percentage of the respondents reported that branches held no relevance for them, as they perform most of their transactions electronically (SMEs: 24 per cent, microenterprises: 20 per cent). Roughly the same percentage indicated that smooth contact with the branch was the most important consideration, but added that the branch's physical proximity to the enterprise's place of business or site was not necessarily required for this (SMEs: 17 per cent, microenterprises: 20 per cent).

We also asked respondents what types of transactions they typically sought to execute when visiting their account manager branch (Figure 23). Both SMEs and microenterprises typically reported visiting the branch for pay-ins or pay-outs; 70 per cent reported making a cash deposit or withdrawing cash from their accounts on these occasions. SMEs were also likely to mention credit administration or other account operations (e.g. management of authorisations): both purposes were cited by almost 40 per cent of the respondents. The former two transaction types are also important for microenterprises, although their share is somewhat smaller, 20 per cent and 27 per cent, respectively. In addition, more than 20 per cent of microenterprises also initiate paper-based credit transfers during personal visits to their branch. 
On balance, we found that Hungarian SMEs and microenterprises are extremely loyal to their banks; indeed, excluding forced bank switches, only slightly more than 10 per cent of the respondents switched account manager financial institutions in the past 3 years. Even though most respondents indicated cost-efficiency as the primary reason for switching banks, we cannot say that Hungarian enterprises are particularly sensitive to cost: the quality of banking services is also considered by most before making such a decision.

\section{Figure 23}

Types of transactions executed in account manager branches Frequency of specific transaction types (\%)

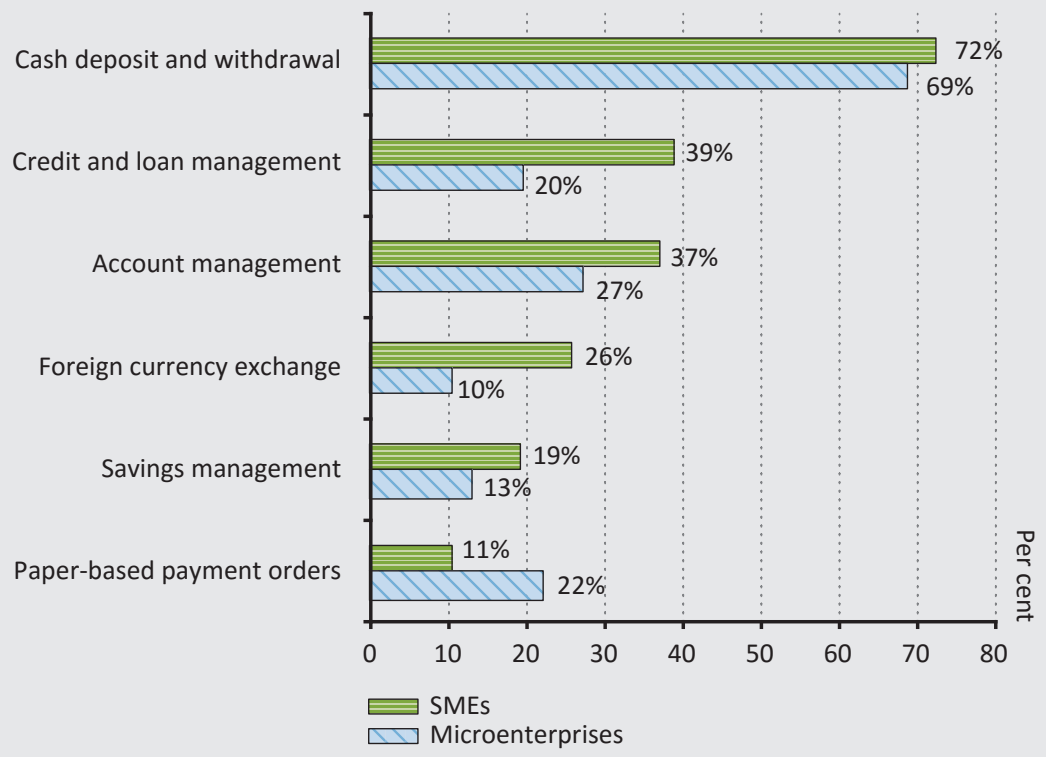

It is another important message gleaned from the survey that the significance of branches from a payment perspective is on the decline in the SME sector; only about 40 per cent of the respondents referred to the importance of easy access to the branch network. By contrast, for more than half of the microenterprises proximity to the account manager bank's branch is still a key criterion in bank selection. Pay-in and pay-out transactions clearly represent the most typical activity performed in the branch; in addition, enterprises are likely to visit their bank for credit administration or for other account operations, while microenterprises still visit their branches for paper-based credit transfers relatively frequently. 


\subsection{How can enterprises' cash usage be retrenched?}

Respondents were asked what would be an incentive for them to replace cash transactions by electronic payment solutions. Although a fairly high percentage of enterprises (31 per cent of SMEs and 20 per cent of microenterprises) reported that the reduction of cash usage was not an important consideration for them and thus, they ignored this issue altogether, the majority of the respondents indicated that they could retrench cash usage primarily in response to positive incentives. Respondents were allowed to pick more than one of the options offered and also to formulate other incentives during the oral interviews in their own words. Enterprises would be most open to the reduction of the costs associated with electronic payment solutions and to the expansion and improvement in the flexibility of electronic banking services (Figure 24). In fact, these possibilities would encourage enterprises even more so than indicated in the figure, given that many of the incentives identified by respondents choosing the "other" category included proposals that can be classified in these categories (e.g. "cheaper credit transfers", "technical improvement on the bank side", "speeding up the four-hour transaction time, even real-time transfers", "revision of transaction taxes").

It is important to emphasise that, based on the results of our survey, a potential increase in the costs of cash transactions would be a far less successful and effective incentive in the efforts to reduce cash usage than positive incentives. The percentage of those who believe that increasing the costs of cash transactions would scale back their use of cash (29 per cent of SMEs and 25 per cent of microenterprises) is less than half of those who believe that reducing the costs of electronic payment solutions would achieve the same result (62 per cent of SMEs and 55 per cent of microenterprises).

Respondents with a high share of cash transactions in their payments who also consider the reduction of cash usage important would be typically most motivated to do so by the reduction of the costs associated with electronic payments. At the same time, however, this segment was no more likely to switch account manager financial institutions over the past 3 years than the total sample. Mainly because of the small size of the relevant sample, in this article we are unable to offer a more detailed analysis of any other common features of the enterprises that belong to the above segment; nevertheless, this would be an important element of further research due to its strong potential to encourage the reduction of cash usage on the part of those who use cash out of necessity. 


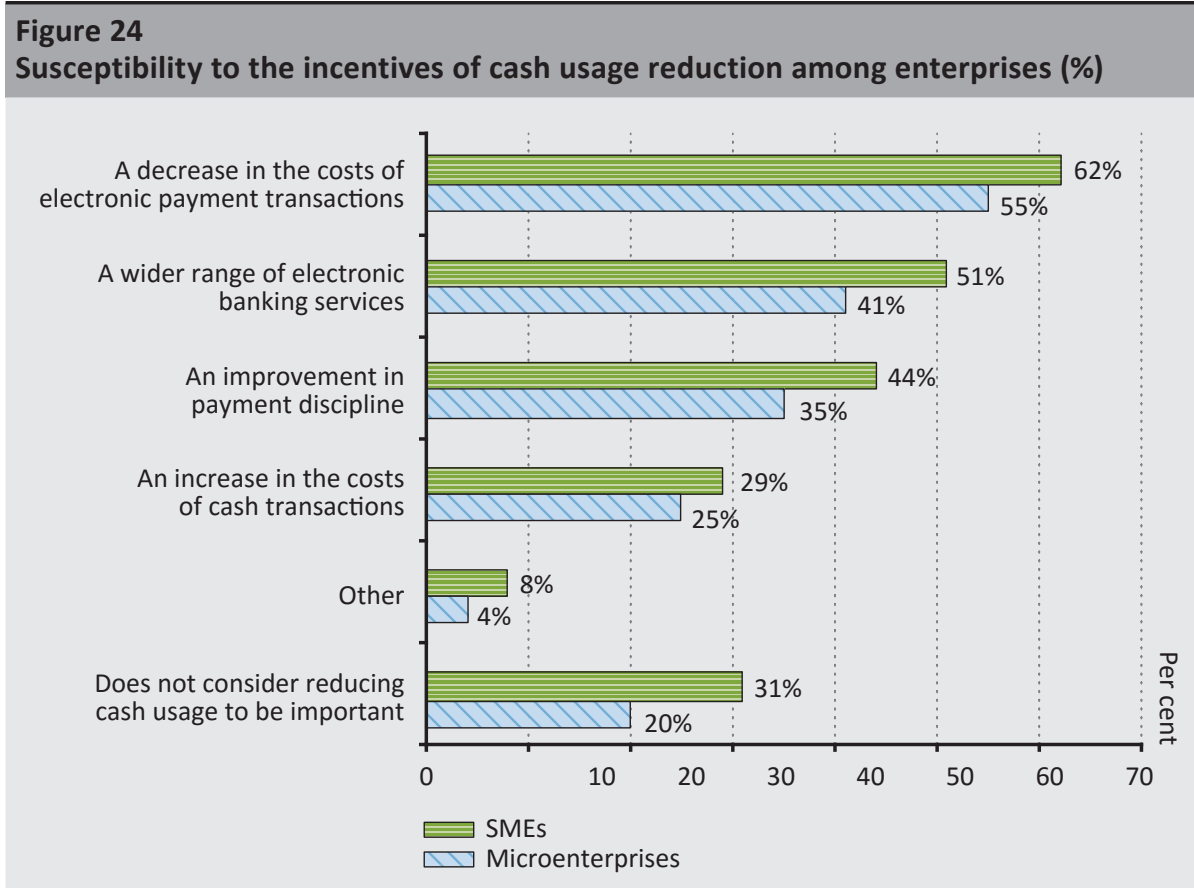

Presumably, enterprises' preference for cash usage may be related to the presence of the shadow economy. This survey, however, was not intended to examine this relationship in more detail and our methodology is not suitable for such purposes in any event. The topic has been addressed in detail both by Hungarian and foreign authors (for example, Rogoff 1998, Bajada-Schneider 2005, Semjén et al. 2009), who confirmed the existence of this relationship, namely, that cash is one of the elements that fuels the operation of the shadow economy.

\subsection{Cash usage correlations}

Although our small sample size limits our ability to perform more complex statistical analyses, we attempted to identify - through regression analysis - which criteria among those we examined may most strongly influence the cash usage of enterprises (separately for SMEs and microenterprises). Since presumably it is not only corporate considerations but also customer preferences that play a role in choosing the payment method of transactions conducted with customers, for the rest of our article we focus our analysis of enterprises' cash usage primarily on the data of supplier relationships. We separately analyse the attributes that affect the cashless operation of enterprises and the percentage thereof in the case of cash users because according to our hypothesis, the correlations behind these two phenomena might be, to some degree, different. 
The dependent variable of our regression estimate in the case of cash-user enterprises is the percentage of cash payments in the enterprise's supplier relationships, while its explanatory variables in the case of microenterprises comprise the percentage of cash payments in the customer relationships of the given enterprise, the dummy variables that classify 2016 sales revenues (using the largest sized group as a benchmark), and an additional dummy variable with a value of 1 if the respondent switched the account manager bank in the past 3 years. In the case of the SME sector two additional dummy variables are used, which capture whether, in the respondent's opinion, it was the introduction of intraday transactions or the adoption of the financial transaction levy that affected the operation of the respondent's enterprise the most (the relevant questions were only included in the questionnaires completed by representatives of small and medium-sized enterprises).

\section{Table 1}

\section{Estimated coefficients of the regressions explaining the cash usage of the SME sector and microenterprises}

\begin{tabular}{|c|c|c|c|}
\hline \multicolumn{2}{|l|}{ SME sector } & \multicolumn{2}{|l|}{ Microenterprises } \\
\hline $\begin{array}{l}\text { Percentage of cash payment in customer } \\
\text { relationships (\%) }\end{array}$ & $0.29 *$ & $\begin{array}{l}\text { Percentage of cash payment in customer } \\
\text { relationships (\%) }\end{array}$ & $0.56^{*}$ \\
\hline \multicolumn{2}{|l|}{2016 sales revenue (HUF 200-500 million) } & \multicolumn{2}{|l|}{2016 sales revenue (HUF 0-25 million) } \\
\hline HUF 0-100 million & $19.53^{*}$ & HUF 25-50 million & $-11.16^{*}$ \\
\hline HUF 100-200 million & $8.85^{*}$ & HUF 50-100 million & $-15.50 *$ \\
\hline HUF 500-1,000 million & -0.21 & above HUF 100 million & $-23.99 *$ \\
\hline above HUF 1,000 million & $-7.78^{*}$ & $\begin{array}{l}\text { Changed its account manager bank in } \\
\text { the past } 3 \text { years }\end{array}$ & $7.07^{*}$ \\
\hline $\begin{array}{l}\text { Introduction of intraday transactions } \\
\text { affected the operation of the enterprise }\end{array}$ & $-6.41 *$ & Constant & $20.68 *$ \\
\hline $\begin{array}{l}\text { Introduction of the financial transaction } \\
\text { levy affected the operation of the } \\
\text { enterprise }\end{array}$ & 2.78 & $\mathrm{~N}$ & 273 \\
\hline $\begin{array}{l}\text { Changed its account manager bank in } \\
\text { the past } 3 \text { years }\end{array}$ & 6.27 & $\mathrm{R}^{2}$ & 0.50 \\
\hline Constant & $11.44 *$ & & \\
\hline $\mathrm{N}$ & 263 & & \\
\hline$R^{2}$ & 0.41 & & \\
\hline
\end{tabular}

The suspicion of multicollinearity may have arisen in the case of the model as the factors that are significant with regard to supplier-side cash usage may also correlate with cash usage on the customer side. However, since the value of VIF indicators ${ }^{11}$ is below 2 for each variable we can exclude any bias.

${ }^{11}$ Variance Inflation Factor: it measures the ratio of the actual variance of the given variable's estimated coefficient to the value that would be received with the total exclusion of multicollinearity. 
The coefficients presented in Table 1 confirm our previous hypothesis that cash inflows from the customer side spill over to supplier relationships, in particular, in the case of microenterprises. Moreover, it is true for both small and medium-sized enterprises and microenterprises that the higher the revenues of an enterprise, the less likely it will be to pay its suppliers in cash. As regards regulatory measures, we found that the percentage of cash transactions is 6.41 per cent lower on average among those respondents who reported that the introduction of intraday transactions affected the operations of the enterprise. Cash transactions in supplier relationships occurred at a higher percentage at microenterprises that switched account manager banks in the past 3 years, which may indirectly suggest that in their case, the use of cash can be attributed to the high costs of electronic payment solutions. As there was no significant relationship between the share of cash usage of the enterprise and the other attributes analysed in our survey (e.g. number of employees, core activity, payment terms, account management costs in the past few years), the model presented above does not include these attributes.

We relied on logistic regression to determine the extent to which specific factors influence cashless operation on the supplier side, as the dependent variable can take two values (1: cashless or 0 : cash user). The explanatory variables in this case comprise the dummy variable that expresses cashless operations in customer relationships and the 2016 sales revenue, as well as the dummy variables classifying the core activity of the enterprise (using the largest sized group as a benchmark).

\begin{tabular}{|c|c|c|c|}
\hline \multicolumn{4}{|l|}{$\begin{array}{l}\text { Table } 2 \\
\text { Estimated coefficients of the } \\
\text { SME sector and microenterpri }\end{array}$} \\
\hline \multicolumn{2}{|l|}{ SME sector } & \multicolumn{2}{|l|}{ Microenterprises } \\
\hline Cashless in customer relationships & $2.17^{*}$ & Cashless in customer relationships & $2.26^{*}$ \\
\hline \multicolumn{2}{|l|}{$\begin{array}{l}2016 \text { sales revenue } \\
\text { (HUF 200-500 million) }\end{array}$} & \multicolumn{2}{|l|}{$\begin{array}{l}2016 \text { sales revenue } \\
\text { (HUF } 0-25 \text { million) }\end{array}$} \\
\hline HUF 0-100 million & 0.28 & HUF 25-50 million & $0.58^{*}$ \\
\hline HUF $100-200$ million & 0.00 & HUF 50-100 million & 0.2 \\
\hline HUF $500-1,000$ million & -0.01 & above HUF 100 million & -0.13 \\
\hline above HUF 1,000 million & $0.81^{*}$ & \multicolumn{2}{|c|}{ Core activity of the enterprise (Other) } \\
\hline \multicolumn{2}{|c|}{ Core activity of the enterprise (Other) } & Construction & $-1.24 *$ \\
\hline Construction & $-0.82^{*}$ & Trade & -0.27 \\
\hline Trade & $0.71^{*}$ & Manufacturing & -0.29 \\
\hline Manufacturing & 0.13 & Constant & $-1.30^{*}$ \\
\hline Constant & $-1.53^{*}$ & N & 487 \\
\hline$N$ & 477 & $R^{2}$ & 0.20 \\
\hline$R^{2}$ & 0.19 & & \\
\hline
\end{tabular}


The estimated coefficients presented in Table 2 can be interpreted as log-odds rates; in other words, they show the extent to which the existence of the given attribute increases (in the case of a positive coefficient) or decreases (in the case of a negative coefficient) the probability rate of cashless operations in supplier relationships compared to the benchmark group. We found, therefore, that enterprises that are cashless in customer relationships are also more likely to execute transactions towards their suppliers electronically, and that similarly, enterprises with higher revenues are more likely, to a certain degree, to operate without cash. It is also important that we found a significant correlation between cashless operation and the core activity of the enterprise: participants of the construction industry are less inclined to stop using cash, whereas small and medium-sized enterprises engaged in trade are more likely to exclusively use electronic payment.

In addition, we thought that analysing the attributes of wage payments in cash was also warranted. As such payments may indirectly influence households' payment habits as well, understanding this phenomenon may play an important part in mapping the role of cash in the Hungarian economy. The dependent variable of the regression estimated for this was the percentage of cash-based wage payments, and its explanatory variables comprised the share of cash payment in supplier relationships and the dummy variables classifying the 2016 sales revenue of the enterprise and its core activity (using the largest sized group as a benchmark). Since the VIF coefficients were below 2 for each variable, the model does not include any multicollinearity.

\begin{tabular}{|c|c|}
\hline $\begin{array}{l}\text { Table } 3 \\
\text { Coefficients of the regression explaining cash-ba }\end{array}$ & e SME s \\
\hline SMES & \\
\hline Percentage of cash payment in supplier relationships (\%) & $0.30 *$ \\
\hline $\begin{array}{l}2016 \text { sales revenue } \\
\text { (HUF 200-500 million) }\end{array}$ & \\
\hline HUF 0-100 million & $15.57^{*}$ \\
\hline HUF $100-200$ million & 3.10 \\
\hline HUF $500-1,000$ million & -5.53 \\
\hline above HUF 1,000 million & $-11.91 *$ \\
\hline Core activity of the enterprise (Other) & \\
\hline Construction & $8.71 *$ \\
\hline Trade & 1.53 \\
\hline Manufacturing & 0.97 \\
\hline Constant & $12.50 *$ \\
\hline N & 469 \\
\hline $\mathrm{R}^{2}$ & 0.18 \\
\hline
\end{tabular}


The coefficients presented in Table 3 demonstrate that, in the SME sector, enterprises preferring the use of cash in supplier transactions also tend to pay wages in cash, and cash-based wage payments are particularly prevalent among the enterprises with the lowest revenues. We can also observe a correlation with the core activity of the enterprise: a higher percentage of the enterprises engaged in construction pay wages in cash. In the case of microenterprises, no significant relationship could be observed between cash-based wage payment and the other attributes we examined.

\section{Main conclusions}

Our study presented the results of the explorative survey conducted among Hungarian micro, small and medium-sized enterprises. The survey was mainly intended to review the cash usage of Hungarian enterprises and to gain a deeper understanding of their payment behaviour. Wherever it proved to be substantiated methodologically, we compared our findings with the results of the survey conducted in 2013 with a similar focus in order to analyse changes in the enterprises' attitude to cash usage and accordingly, in the payment habits they exhibited in business relations. The main findings of our research were the following:

- The most typical payment method among Hungarian micro, small and mediumsized enterprises is credit transfer: most enterprises rely on this payment method in their business relations, in supplier and customer positions alike.

- Despite the clear dominance of bank transfers, we found that the use of cash still has a strong presence among Hungarian SMEs and microenterprises-especially in the case of low-value transactions and those exceeding HUF 500,000 - without any decline in its role and significance in the past four years.

- Despite the dynamic development in the cashless infrastructure, in certain areas we observed an unfavourable shift in the cash payment practice of SMEs compared to the 2013 survey: the percentage of enterprises using cash in supplier transactions increased, and there was also an increase in the number of enterprises that used cash for large-value transactions both in their supplier and customer relationships. At the same time, our regression analysis confirmed our initial hypothesis; namely, that cash usage declines in line with the increase in enterprise size.

- In addition to cash payments used in B2B relationships, we should stress that the respondent enterprises - in particular, microenterprises - also pay a large percentage of wages in cash, which generates further cash usage in B2C relationships. 
- Most enterprises justified their use of cash by executing low-value transactions, but the increase in the share of high-value cash transactions appear to contradict this statement somewhat. The results of the survey are much more likely to suggest that the use of cash is more like a deep-rooted attitude in the operation of the enterprises. Many of them resort to cash usage out of habit, and cash payment is still the simplest payment method in on-the-spot payments. Accordingly, cash inflows - typically from the customer side - proceed "unhindered" through the business relations of the enterprises and find their way back to an enterprise's bank account partially only or after having reversed directions several times.

- The research results received in the area of payment behaviour (payment discipline, observation of payment terms, overdue receivables and bad debts) clearly indicate that the business environment and hence payment discipline of enterprises has improved significantly in the SME sector. This shift is a clear positive message with regard to the operability and growth potential of the SME sector. It also suggests that the general distrust observed among the enterprises in the wake of the crisis has moderated, and the signs of this moderation are now also reflected in the payment discipline of the enterprises. The lack of trust that can now be observed primarily in customer relationships is far less likely to justify the use of tight payment terms and cash payments among SMEs.

- Micro, small and medium-sized enterprises are extremely loyal in their bank relations; bank switching among them is remarkably rare. It is a positive shift that SMEs are far more open to electronic payment solutions than four years ago. Most cash-user enterprises would be willing to reduce the use of cash if electronic payment solutions and the related banking services were available more inexpensively, flexibly, and in a way more tailored to their personal needs (more than twice as many enterprise would be willing to restrain their cash usage in response to the reduction of the costs associated with electronic payment solutions than those doing the same in response to an increase in the costs of cash transactions). Nevertheless, our data suggest that the percentage of those willing to switch banks to that end is far lower.

- Based on our research it is a reasonable assumption that there is significant demand for the introduction of broadly available, inexpensive, instant payment solutions, which could be also used in situations where currently cash payment represents the only real alternative. This assumption is supported by the fact that around one quarter of the enterprises replaced some of their cash payments by electronic credit transfers after the introduction of intraday transactions.

- There is no evidence for a direct relationship between the financial transaction levy and the enterprises' use of cash; however, the levy presumably plays an indirect role in the fact that transaction costs are perceived as high by the 
respondents. As a further consequence, enterprises may also use their cash inflows in their supplier relationships.

- The payment habits of the SME sector are expected to change - perhaps significantly - in the coming years as a result of the introduction of the system of "online invoicing" as from 1 July 2018 (i.e. mandatory data supply to the National Tax and Customs Administration on electronically issued invoices within a 24-hour time limit) and as a result of the instant payment system infrastructure to be implemented, in accordance with the MNB's decision, by GIRO Zrt. by the second half of 2019, which guarantees that transactions are cleared within 5 seconds every day of the year.

\section{References}

Bajada, C. - Schneider, F. (Eds.) (2005): Size, Causes and Consequences of the Underground Economy: An International Perspective. Ashgate, Aldershot, United Kingdom.

Banai, Á. - Körmendi, Gy. - Lang, P. - Vágó, N. (2016): Modelling the credit risk of the Hungarian SME sector. MNB Occasional Papers 123. http://www.mnb.hu/letoltes/mnb-op123-final.pdf. Downloaded: 18 January 2018.

Bethlendi, A. - Végh, R. (2014): Crowdfunding - could it become a viable option for Hungarian small businesses? Financial and Economic Review, 13(4): 100-124. http:// english.hitelintezetiszemle.hu/letoltes/5-bethlendi-vegh-en.pdf

Bódi-Schubert, A. (2014): Bizalom és fizetési magatartás a kis- és középvállalatok üzleti kapcsolataiban (Trust and payment behaviour in the business relations of small and medium-sized enterprises). MNB Occasional Papers 110. http://www.mnb.hu/letoltes/ mt110-vegleges.pdf. Downloaded: 12 January 2018.

Burkart, M. - Ellingsen, T. (2004): In-Kind Finance: A Theory of Trade Credit. American Economic Review, 94(3): 569-590. https://doi.org/10.1257/0002828041464579

Esselink, H. - Hernández, L. (2017): The use of cash by households in the euro area. ECB Occasional Paper Series, No. 201. https://www.ecb.europa.eu/pub/pdf/scpops/ecb.op201. en.pdf. Downloaded: 18 January 2018

Havran, D. - Kerényi, P. - Víg, A. (2017): Trade Credit or Bank Credit? - Lessons Learned from Hungarian Firms between 2010 and 2015. Financial and Economic Review, 16(4): 86-121. http://doi.org/10.25201/FER.16.4.86121

HCSO (2017): A kis- és középvállalkozások helyzete hazánkban 2016 (The status of small and medium-sized enterprises in Hungary 2016). http://www.ksh.hu/docs/hun/xftp/idoszaki/ pdf/kkv16.pdf. Downloaded: 12 January 2018. 
Ilyés, T. - Takács, K. - Varga, L. (2014): Changes in the fees on payment services and the structure of payments following the introduction of the financial transaction tax. MNB Bulletin, March: 40-48. https://www.mnb.hu/letoltes/ilyes-takacs-varga.pdf. Downloaded: 15 January 2018.

Ilyés, T. - Varga, L. (2015): Show me how you pay and I will tell you who you are - Sociodemographic determinants of payment habits. Financial and Economic Review, 14(2): 25-61. http://english.hitelintezetiszemle.hu/letoltes/2-ilyes-varga-en.pdf

Intrum Justitia (2017): European Payment Report 2017. https://www.ijcof.fr/globalassets/ countries/france/pdfs/epr-2017.pdf. Downloaded: 12 January 2018.

McGuiness, G. - Hogan, T. - Powell, R. (2018): European trade credit use and SME survival. Journal of Corporate Finance, 49 (April): 81-103. https://doi.org/10.1016/j. jcorpfin.2017.12.005

MNB (2018): Payment Systems Report 2018. http://www.mnb.hu/letoltes/payment-systemsreport-june-2018-vegleges.pdf. Downloaded: 20 June 2018.

Rogoff, K. (1998): Blessing or curse? Foreign and underground demand for euro notes. Economic Policy, 13(26): 261-303. https://doi.org/10.1111/1468-0327.00033

Semjén, A. - Tóth, I. J. - Medgyesi, M. - Czibik, Á. (2009): Adócsalás és korrupció - lakossági érintettség és elfogadottság (Tax evasion and corruption: Population involvement and acceptance). In: Semjén, A. - Tóth, I. J. (eds.): Rejtett gazdaság - Be nem jelentett foglalkoztatás és jövedelemeltitkolás - kormányzati lépések és a gazdasági szereplők válaszai (Hidden economy Undeclared employment and non-reported income: Government policies and the reaction of economic agents). Institute of Economics Discussion Papers, pp. 228-258. Hungarian Academy of Sciences. Budapest.

Tu, T. - Salmon, C. (2016): Uses of Cash and Electronic Payments. https://assets.publishing. service.gov.uk/government/ uploads/system/uploads/attachment_data/file/557331/ Uses_of_Cash_and_Electronic_Payment.pdf. Downloaded: 16 January 2018. 


\section{Annex}

Structure of the quantitative questionnaire applied for the survey on the payment habits of Hungarian micro, small and medium-sized enterprises

1. Questions on company demographics (core activity, staff number, net sales revenues), the respondent's position at the enterprise

2. Payment habits in supplier relationships

- Payment methods applied by the enterprise in supplier relationships (multiple choice question allowing multiple answers: cash payment; credit transfer; card payment; other, namely)

- Rate at which the enterprise applies specific payment types (as a percentage of all payment transactions)

- Typical average value of specific cash payment transactions (multiple choice: below HUF 50,000; HUF 50,000 - 100,000; HUF 100,001 - 500,000; above HUF $500,000)$

- Reason for the use of cash in supplier relationships at the enterprise (multiple choice question allowing multiple answers: low value; simultaneous exchange of goods and money; the only way for on-the-spot payments; habit; fear of nonpayment; quickness; inexpensiveness (low transaction cost); possibility of avoiding invoicing; suppliers prefer to execute their transactions in cash; other, namely)

- Typical payment terms of business transactions with suppliers (multiple choice: advance payment of the full purchase price is required; instant, simultaneous cash payment; payment terms of 8 days or less; payment terms between 8 and 30 days; payment terms of 30 days; payment terms between 30 and 60 days; payment terms between 60 and 90 days; payment terms of more than 90 days)

- Does the enterprise have any overdue supplier accounts at present and if yes, in what amount (multiple choice: below HUF 1 million; HUF 1-5 million; HUF 5-10 million; above HUF 10 million)

\section{Payment habits in customer relationships}

- Payment methods applied by the enterprise in customer relationships (multiple choice question allowing multiple answers: cash payment; credit transfer; card payment; other, namely)

- Rate at which the enterprise applies specific payment types (as a percentage of all payment transactions) 
- Typical average value of specific cash payment transactions (multiple choice: below HUF 50,000; HUF 50,000 - 100,000; HUF 100,001 - 500,000; above HUF $500,000)$

- Reason for the use of cash in customer relationships at the enterprise (multiple choice question allowing multiple answers: low value; simultaneous exchange of goods and money; the only way for on-the-spot payments; habit; fear of nonpayment; quickness; inexpensiveness (low transaction cost); possibility of avoiding invoicing; customers prefer to pay in cash; other, namely)

- Typical payment terms applied by the enterprise in sale transactions to customers (multiple choice: advance payment of the full purchase price is required; instant, simultaneous cash payment; payment terms of 8 days or less; payment terms between 8 and 30 days; payment terms of 30 days; payment terms between 30 and 60 days; payment terms between 60 and 90 days; payment terms of more than 90 days)

- Does the enterprise apply different payment conditions for old and new customers and if yes, how (multiple choice: payment conditions are tighter for new customers; payment conditions are less tight for new customers)

- Do the following criteria play a role in determining the payment conditions for new customers (yes/no, if yes, more than one answer can be chosen): the new customer's market reputation; recommendations of debt rating agencies; the payment conditions are subject to negotiation; other, namely

- Did it happen in the past three years that the enterprise changed its payment conditions in an existing customer relationship (yes/no) and if yes, how (multiple choice: it typically tightened payment conditions; it typically eased payment conditions)

- How typical it is for the enterprise to consider assessments by debt rating or debtor rating agencies in formulating its payment conditions for customers (multiple choice: they are regularly considered; they are considered occasionally or as needed; they do not consider such assessments)

- Does the enterprise have overdue account receivables at present (yes/no) and if yes, in what amount (multiple choice: below HUF 1 million; HUF 1-5 million; HUF 5-10 million; above HUF 10 million)

- Did the enterprise have any bad debt loss in the past three years (yes/no) and if yes, in what total amount (multiple choice: below HUF 1 million; HUF 1-5 million; HUF 5-10 million; above HUF 10 million) 
4. Typical payment habits in the payment of utility bills and wages

- Payment methods typically applied by the enterprise for the payment of utility bills (multiple choice allowing multiple answers: cash payment; postal inpayment money order ("yellow cheque"); credit transfer; direct debit; other)

- At what rate does the enterprise pay employees' wages in cash and in credit transfer (in percentages, exclusively in relation to wages without any cafeteria, passes and other benefits; in the case of variable wages calculated for an average month)

5. Impact of regulatory measures (intraday transaction, financial transaction levy), incentives for the reduction of cash usage

- Is there any perceivable significance of the availability of intraday transactions for the enterprise (yes/no) and if yes, are the following statements true for the enterprise in the respondent's opinion (true/untrue): it simplified the execution and controllability of payment transactions; it yielded liquidity and cost efficiency benefits; it made the execution of bank transfers faster and more convenient; it was able to replace cash transactions by electronic credit transfers; other, namely

- Did the account management fees of the enterprise change in the past 1-3 years (yes/no) and if yes, how (multiple choice: they increased moderately; they increased significantly; they decreased moderately; they decreased significantly)

- In the respondent's opinion did the financial transaction levy change the enterprise's payment practice (yes/no) and if yes, how (multiple choice question allowing multiple answers: the enterprise tries to consolidate individual electronic payments to partners in order to reach the upper limit of the levy; it performs a higher percentage of e-payments via foreign banks; it chose a bank service where the financial institution assumes a portion of the transaction levy; it performs more outgoing payments in cash rather than electronically; more incoming payments are received in cash rather than electronically; other, namely)

- Would the factors listed below encourage the enterprise to replace cash transactions by electronic payment solutions (yes/no, multiple answers are allowed: an increase in payment discipline between the enterprises; a decline in the costs (e.g. merchant service fees, account management fees, transaction fees) of electronic payment solutions; an increase in the cost of cash transactions; an expansion in electronic bank services and their increased flexibility; other, namely; the respondent does not consider the reduction of cash payments important) 
6. The enterprise's credit institution relations, bank selection, bank switching

- Did the enterprise change its account manager financial institution in the past 1-3 years (yes/no) and if yes, what was the main reason behind this step (multiple choice: cost efficiency; more convenient and personalised service; more favourable financial service package (e.g. terms and conditions of account management); dissatisfaction with the previous financial institution; customer relations, the service was unsatisfactory at the previous financial institution; proximity; opening hours; other, namely)

- If the switch was justified by other reasons in addition to the main reason, what was it (multiple choice: cost efficiency; more convenient service tailored to the enterprise's needs; more favourable financial service package (e.g. terms and conditions of account management); dissatisfaction with the previous financial institution; customer relations, the service was unsatisfactory at the previous financial institution; proximity; opening hours; other, namely)

- In selecting the account manager financial institution, several factors may be of significance. Which of the following statements does the respondent agree with the most: I only choose a financial institution that has a branch near my registered office/site; the proximity of the branch network is even more important to me than account management fees; if I get better bank fees or services I am willing to maintain a relationship with a branch even in a more distant city/district; I only choose a financial institution with which I can keep in touch smoothly; branches have no significance to me - for the most part, I handle my account transactions electronically

- If the respondent visits the account manager branch of its enterprise, what type of transactions does he typically execute (multiple choice question allowing multiple answers: cash pay-ins and pay-outs; currency exchange services; placing paper-based credit transfer orders; other account operations (e.g. management of authorisations); administrative tasks related to savings; credit administration) 